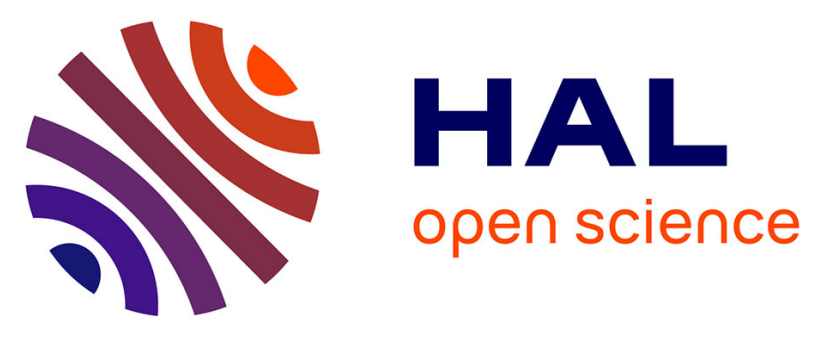

\title{
Mice lacking the serotonin 5-HT2B receptor as an animal model of resistance to selective serotonin reuptake inhibitors antidepressants.
}

Silvina Laura Diaz, Nicolas Narboux-Nême, Katia Boutourlinsky, Stéphane Doly, Luc Maroteaux

\section{To cite this version:}

Silvina Laura Diaz, Nicolas Narboux-Nême, Katia Boutourlinsky, Stéphane Doly, Luc Maroteaux. Mice lacking the serotonin 5-HT2B receptor as an animal model of resistance to selective serotonin reuptake inhibitors antidepressants.. European Neuropsychopharmacology, 2015, 26 (2), pp.265-279. 10.1016/j.euroneuro.2015.12.012 . hal-01253863

\section{HAL Id: hal-01253863 https://hal.science/hal-01253863}

Submitted on 18 Feb 2016

HAL is a multi-disciplinary open access archive for the deposit and dissemination of scientific research documents, whether they are published or not. The documents may come from teaching and research institutions in France or abroad, or from public or private research centers.
L'archive ouverte pluridisciplinaire HAL, est destinée au dépôt et à la diffusion de documents scientifiques de niveau recherche, publiés ou non, émanant des établissements d'enseignement et de recherche français ou étrangers, des laboratoires publics ou privés. 


\title{
Research article
}

Mice lacking the serotonin $5-\mathrm{HT}_{2 \mathrm{~B}}$ receptor as an animal model of resistance to selective serotonin reuptake inhibitors antidepressants

\section{Short title: 5-HT $2 B$ receptor in SSRI antidepressant effects}

Silvina Laura Diaz†, Nicolas Narboux-Nême, Katia Boutourlinsky, Stéphane Doly, and Luc Maroteaux*

INSERM UMR-S 839, F75005, Paris, France; Université Pierre et Marie Curie, F75005, Paris; Institut du Fer à Moulin, F75005, Paris.

$\uparrow$ Present address: Instituto de Biología Celular y Neurociencia Prof. E. De Robertis, UBA - CONICET, Paraguay $2155,3^{\circ}$ piso, C1121ABG, Buenos Aires, Argentina

*Corresponding author : Luc Maroteaux, Institut du Fer à Moulin UMR-S839 INSERM/UPMC 17 rue du Fer à Moulin 75005 Paris

Tel : (33) $0145876123 \quad$ Fax : (33) $0145876132 \quad$ Email : luc.maroteaux@upmc.fr

\section{Statistical Summary}

Word Count of the abstract 231

Word Count the body of the manuscript 6276

Number of references 46

Number of figures and tables 6

\begin{abstract}
Depressive disorders are among the most prevalent neuropsychiatric dysfunctions worldwide, with high rates of resistance to antidepressant treatment. Genetic factors clearly contribute to the manifestation of depression as well as to the response to antidepressants. Transgenic mouse models appear as seminal tools to disentangle this complex disorder. Here, we analyzed new key aspects of the phenotype of knock-out mice for the gene encoding the serotonin $2 \mathrm{~B}$ receptor $\left(\mathrm{Htr}_{2 B}{ }^{-/-}\right)$, including basal phenotype, ability to develop a depressive-like phenotype upon chronic isolation, and effect of chronic exposure to fluoxetine on chronically stressed $\mathrm{Htr}_{2 B}{ }^{-/-}$mice. We find, here, that $\mathrm{Htr}_{2 B}{ }^{-/-}$mice display an antidepressant-like phenotype, which includes reduced latency to feed in the Novelty Suppressed Feeding test, basal increase in hippocampal BDNF levels, no change in TrkB and p75 protein levels, and an increased preference for sucrose consumption compared to wild type $\left(\mathrm{Htr}_{2 B}{ }^{+/+}\right)$mice. Nevertheless, we show that these mice can develop depressive-like behaviors when socially isolated during four weeks. Selective serotonin reuptake inhibitors (SSRI) have been previously shown to be ineffective in non-stressed $\mathrm{Htr}_{2 B}{ }^{-/-}$mice. We evaluated, here, the effects of the SSRI fluoxetine in chronically stressed $\mathrm{Htr}_{2 B}{ }^{-/-}$mice and, similarly, no behavioral or plastic effect was induced by this antidepressant. All together, these results highlight the suitability to study resistance to SSRI antidepressants of this mouse model, displaying panoply of conditions among which, behavioral, neurotrophic and plastic causative factors can be analyzed.
\end{abstract}

Keywords: Serotonin; 5-HT $2 \mathrm{~B}$ receptor; chronic stress; SSRI antidepressants; depression; mice 


\section{INTRODUCTION}

Major depressive disorder is one of the neuropsychiatric illnesses producing higher economic burden, with depressed patients hampered to perform daily tasks. Given that an important proportion of depressed patients does not respond to available treatments, increasing efforts in research have been devoted to disentangling the ethiopatogeny around this illness and search for new pharmacological targets. However, only mild progress has been achieved in any of these two aspects (Kupfer et al., 2012). Depression is a complex health issue with genetic, social, physical and environmental factors contributing to its etiology. Therefore, animal models cannot completely recapitulate this heterogeneous illness. Nevertheless, available paradigms and tests can provide key and relevant neurobiological insights to bring light to the understanding of this pathology (Southwick and Charney, 2012).

We have recently shown that mice with genetic or pharmacological ablation of the serotonin receptor 2B subtype $\left(H_{t} r_{2 B}\right)$ do not respond to selective serotonin reuptake inhibitor (SSRI) antidepressants (Diaz et al., 2012; Diaz and Maroteaux, 2011). Indeed, neither acute nor chronic classical SSRI effects have been observed in knockout mice for the 5- $\mathrm{HT}_{2 \mathrm{~B}}$ receptor gene $\left(\mathrm{Htr}_{2 B}{ }^{-/}\right)$. Interestingly, the basal response of $\mathrm{Htr}_{2 B}{ }^{-/-}$mice in the novelty suppressed feeding (NSF) test is similar to that of chronically SSRItreated mice (Diaz et al., 2012). An antidepressant-like phenotype can be described as an animal expressing a repertoire of signs similar to those induced by the chronic administration of antidepressants. Therefore, the phenotype of the $\mathrm{Htr}_{2 B}{ }^{-/-}$mice in the NSF test could represent part of an antidepressant-like phenotype, but a better characterization is required.

Built on the observation that stressful events can precipitate a depressive state in humans, several animal models have been settled to study depressive disorder (for a review see (Cryan and Mombereau, 2004). Specifically, the unpredictable chronic mild stress (UCMS) originally developed in rats (Willner et al., 1992), and adapted to mice (Ducottet et al., 2004; Santarelli et al., 2003), is a paradigm in which animals are faced to unpredictable stressors during several weeks. As a result, animals develop anhedonic signs, and hence, a depressive-like state could be characterized. We have recently demonstrated that the UCMS protocol appears to have severe rather than mild effects in inbred 129S2/SvPas mice, the background strain of the embryonic stem cells used to generate $\mathrm{Htr}_{2 B}{ }^{-/-}$mice. In fact, 129S2/SvPas mice submitted to UCMS display marked features of stress and are irresponsive to antidepressants, whereas social isolation was revealed as a more confident and appropriate paradigm for 129 strains (Diaz and Maroteaux, 2015). In addition, as depression in humans is believed to be elicited by social stress rather than physical stress, the proposed social isolation model might better meet the etiological validity criteria (Blazer and Hybels, 2005).

The experiments presented herein were, therefore, conducted to address the following questions: 1) Do $\mathrm{Htr}_{2 B}{ }^{-/-}$mice present an antidepressant-like phenotype? 2) Are $\mathrm{Htr}_{2 B}{ }^{-/-}$mice able to develop a depressive-like state when submitted to experimental chronic isolation? and 3) If $\mathrm{Htr}_{2 B}{ }^{-/-}$mice respond to the chronic isolation paradigm, are they able to respond to SSRI antidepressant treatment? To answer these questions, we analyzed key aspects of the $\mathrm{Htr}_{2 B}{ }^{-/-}$mice phenotype and an antidepressant-like phenotype was confirmed. We also demonstrated that $\mathrm{Htr}_{2 B}{ }^{-/-}$mice are able to develop a depressive-like phenotype when exposed to chronic isolation as wild type $\left(\mathrm{Htr}_{2 B}{ }^{+/+}\right)$mice do. Finally, by classical assays to evaluate chronic antidepressant effects, we verified that chronically stressed $\mathrm{Htr}_{2 B}{ }^{-{ }_{-}}$mice are still non-responsive to SSRIs, representing, therefore, a useful model for the study of resistance to antidepressants. 


\section{EXPERIMENTAL PROCEDURES}

\subsection{Animals}

For all the experiments, 7- 9 week-old, male mice were used. $\mathrm{Htr}_{2 B}{ }^{+/+}$and $\mathrm{Htr}_{2 B}{ }^{-/-}$mice were on a 129S2/SvPas background as the embryonic stem cells used for homologous recombination. These animals were derived from heterozygote crosses and bred at the animal facilities of the Fer à Moulin Institute. Behavioral tests and animal care were conducted in accordance with standard ethical guidelines (National Institutes of Health's "Guide for the Care and Use of Laboratory animals", and European Directive 2010/63/UE), and have been approved by local ethical committee ( $\left.\mathrm{N}^{\circ} 1170.01\right)$. All mice were maintained on a 12-light/ dark schedule (lights on at 8:00), temperature of $\left(18-23^{\circ} \mathrm{C}\right)$ with $40-60 \%$ humidity, and housed in groups of 3-5 of the same genetic background and sex after weaning until the beginning of the experimental protocol. Mice were randomly assigned to the different experimental groups. In all the studies, the observer was blind to the experimental conditions being measured.

\subsection{In situ Hybridization}

Naïve mice ( $\mathrm{n}=5-6$ per genotype) were deeply anesthetized with xylazine $(2 \mathrm{mg} / \mathrm{kg}$ i.p.) plus pentobarbital $(50 \mathrm{mg} / \mathrm{kg}$ ) and transcardially perfused with $5 \mathrm{ml}$ of $\mathrm{NaCl} 0.9 \%$ and $50 \mathrm{ml}$ of $4 \%$ paraformaldehyde in 0.1 $\mathrm{M}$ phosphate-buffered saline (1X PBS, $\mathrm{pH} 7.4$ ) for 15 minutes. Brains were recovered and postfixed for 24 $\mathrm{h}$ at $4^{\circ} \mathrm{C}$ in the same solution. Then, $50 \mu \mathrm{m}$ thick coronal sections through the entire hippocampus and raphe were obtained on a vibratome. Sections were stored at $-20^{\circ} \mathrm{C}$ in cryoprotectant solution until use. Coronal sections were employed for in situ hybridization, performed as previously described (Bally-Cuif and Wassef, 1994) on a pool of two coronal free-floating sections per mouse from each experimental group $\left(H t r_{2 B}{ }^{+/+}\right.$and $\mathrm{Htr}_{2 B}{ }^{-/-}$). Bdnf (Bdnf probe, consisting in $283 \mathrm{bp}$ from ATG, a kind gift from Dr Koibuchi) or Sert (full SERT cDNA probe) dig-UTP-labeled probes were used and detected using an antibody coupled to alkaline phosphatase (AP, 1/2000, Roche). AP activity was revealed using NBT/BCIP. The total number of $B d n f$-labeled cells in the dentate gyrus was quantified in each section with a bright-field microscope at 40X magnification.

\subsection{Immunofluorescence}

Coronal sections from the same experimental subjects used for in situ hybridization studies were employed. Free-floating sections were first incubated overnight in $0.1 \% \mathrm{H}_{2} \mathrm{O}_{2}$. After rinsing in $1 \mathrm{X} \mathrm{PBS}$, sections were blocked in $0.2 \%$ gelatin and $0.5 \%$ triton in $1 \mathrm{X}$ PBS solution for $1 \mathrm{~h}$. Sections were incubated overnight with rabbit anti BDNF (1:1000; Santa Cruz: sc-546) at $4^{\circ} \mathrm{C}$, and, after washing, exposed to the secondary goat anti rabbit $\mathrm{Cy} 31: 400$ for $2 \mathrm{~h}$ at room temperature. Finally, sections were cover-slipped in antifading mounting medium (mowiol-DABCO $25 \mathrm{mg} / \mathrm{ml}$ ). A region of interest was defined in the dentate gyrus (DG) for each section and BDNF intensity was measured in the selected area using ImageJ software. BDNF signal is expressed after subtraction of background signal.

\subsection{Western blot}

Mice were sacrificed and hippocampus was immediately dissected, homogenized in cold RIPA buffer (Santa Cruz, sc-24948) and centrifuged at 15,000 g for $30 \mathrm{~min}$. Protein concentrations of extracts (supernatants) were measured using the BCA Protein Assay Kit (Sigma BCA1 and B9643) with bovine serum albumin as standard. Equivalent amounts of protein for each sample (50-75 $\mu \mathrm{g})$ were resolved in 4$12 \%$ or $10 \%$ NuPAGE BisTris gels (Invitrogen), then transferred to nitrocellulose membranes (HybondECL; Amersham) and blocked in TBS buffer containing $5 \%$ non-fatty milk for $1 \mathrm{~h}$ at room temperature. Blots were incubated with mouse anti TrkB receptors (1:500; BD Transduction Laboratories, 610101); or goat anti p75 (NGF R/TNFRSF16) receptor (1:1000; R\&DSystems, BAF1157) overnight at $4^{\circ} \mathrm{C}$. Primary antibodies were detected using IRDye 700- or 800-conjugated second antibodies (Rockland, distributor: TEBU, Le Perray en Yveline, France). Binding of the fluorescent antibodies was visualized and quantified using the Odyssey Imaging System (LI-COR biosciences). Tubulin was used as internal protein control (mouse anti tubulin; 1:100,000 Santa Cruz). Protein levels in each experimental condition were normalized to tubulin levels and expressed as a percentage of those in $\mathrm{Htr}_{2 B}{ }^{+/+}$mice. 


\subsection{Novelty-Suppressed Feeding Test}

The NSF paradigm is a conflict test that elicits competing motivations: the drive to eat and the fear of venturing into the center of a brightly lit arena. The NSF was conducted as previously described (Diaz et al., 2012). Briefly, the testing apparatus consisted of a plastic box, $37 \mathrm{~cm}$ x $57 \mathrm{~cm} \times 10 \mathrm{~cm}$, directly illuminated by a white light. The floor was covered with $2 \mathrm{~cm}$ of sawdust. Eighteen hours before the test, food was removed from mouse cages. At the time of testing, a single pellet of a familiar food was placed in the center of the box. An animal was placed in a corner of the box, and a stopwatch was immediately started. The latency to start eating (defined as the mouse sitting on its haunches and biting the pellet with the use of forepaws) was recorded for a 5-min period in non-stressed mice (Santarelli et al., 2003) and 10 min for chronically isolated mice. Immediately after, each mouse was put back in its cage, and food consumption in the home cage was measured during $15 \mathrm{~min}$.

\subsection{Sucrose consumption}

Two cohorts, one for sucrose $2 \%$ and the other for sucrose $8 \%$ of male $\mathrm{Htr}_{2 B}{ }^{+/+}$and $\mathrm{Htr}_{2 B}{ }^{-/}$mice $(\mathrm{n}=8-13$ per group) were tested using a two-bottle choice drinking procedure. Mice were isolated in individual cages, with access to tap water and sucrose delivered in habitual bottles. Mice were allowed to habituate to the housing and drinking conditions for four weeks. During this phase, bottles were interchanged regularly to avoid association between the content and the position (left or right) of the bottles or side preferences. At the end of the each week, bottles were weighed during 2 consecutive days. Sucrose and water daily consumption was calculated by subtraction of consumption values of each solution of the previous day. Daily consumption from each bottle $(\mathrm{ml})$ was used in combination with body weight to calculate sucrose intake $(\mathrm{ml} / \mathrm{kg}$ ) and water consumption $(\mathrm{ml} / \mathrm{kg}$ ). Finally, preference ratio was calculated (sucrose intake/sucrose + water intake).

2.7 Open field test: Mice were placed in an open field area constituting by a $70 \times 70 \times 29 \mathrm{~cm}$ wooden box, which was painted black. On the bottom of the box, white lines divided the field into 25 equal squares. Sixteen squares delimited the peripheral area (PA), and nine the central area (CA). The bottom of the box was covered with urine-proof varnish. Illumination was provided by a single source (3000 lux) placed 2.8 $\mathrm{m}$ above the center of the field's floor. Individual animals were gently placed in the same corner of the apparatus in all trials. The open field tests were conducted during $9 \mathrm{~min}$. At the end of each test, the open field was wiped clean with a slightly damp cloth.

2.8 Elevated plus maze: The maze was elevated to a height of $50 \mathrm{~cm}$ with two open $(30 \times 8.5 \mathrm{~cm})$ and two enclosed arms $(30 \times 8.5 \times 17.5 \mathrm{~cm})$, arranged so that the arms of the same type were opposite each other, connected by an open central area. At the beginning of the experiment, each mouse was placed individually in the center of the maze, facing one of the open arms and observed for $5 \mathrm{~min}$. Different measures were recorded: Number of open-arm entries (an arm entry was defined as all four paws inside the arm), time spent in the open arms, time spent in closed arms.

\subsection{Chronic Social Isolation}

Chronically isolated $\mathrm{Htr}_{2 B}{ }^{+/+}$and $\mathrm{Htr}_{2 B}{ }^{-/-}$mice were put in small individual cages $(267 \mathrm{x} 207 \mathrm{x} 140 \mathrm{~mm})$, whereas group-housed mice stayed in groups of 4-5 in a separate room $(n=9-10$ for each experimental group). Coat state and grooming after splash test were assessed once a week throughout the four weeks. At the end of the week four, mice were euthanized, perfused and brains were collected to study cell proliferation.

\subsection{Coat score}

The assessment of the interest of mice for the state of their fur has been proposed as a valid outcome to evaluate reduced self-care in stressed mice (Ibarguen-Vargas et al., 2008). The state of the coat was determined as previously described (Diaz and Maroteaux, 2015). The total score for coat state was the sum of the scores obtained from six different body parts: head, neck, dorsal coat, ventral coat, forepaws and 
hind paws. Each mouse was taken out of the cage and carefully observed: for each body area, a score of 0 was given for a well-groomed coat and 1 for an unkempt coat. The basal state of the coat was evaluated before starting chronic isolation.

\subsection{Splash test}

This behavioral test is also based on the interest in hygienic habits when the fur is dirty. The state of the coat was determined as previously described (Diaz and Maroteaux, 2015; Ibarguen-Vargas et al., 2008). Briefly, $200 \mu \mathrm{l}$ of a $10 \%$ sucrose solution were squirted on the dorsal coat of the mouse while the mouse is in its current environment (to avoid any other distractor). Immediately after, the time spent grooming is recorded during a 5 minutes period.

\subsection{Cell proliferation assay}

Brain tissues for the cell proliferation assay were obtained as described above for in situ hybridization experiments (2.2). Newborn cells were detected by peroxidase immunostaining of Ki67, an endogenous marker of cell division with similar output as BrdU incorporation as previously described (Diaz et al., 2012; Diaz and Maroteaux, 2015). Briefly, free-floating sections were first blocked in $0.2 \%$ gelatin and $0.5 \%$ triton in $1 \mathrm{X}$ PBS solution for $1 \mathrm{~h}$, and then incubated overnight with the primary antibody (rabbit anti-Ki67 1:1000; Novocastra: NCL-Ki67p) at $4^{\circ} \mathrm{C}$. After washing, sections were exposed to the secondary biotinylated antibody (goat anti rabbit, 1:400; Vector) for $2 \mathrm{~h}$ at room temperature and to 1:400 Streptavidin-biotinylated horseradish peroxidase complex (Amersham). Sections were incubated in Tris $0.1 \mathrm{M}$-DAB 3\%-triton $0.1 \%$ solution for $30 \mathrm{~min}$, and finally, 5\%o of $\mathrm{H}_{2} \mathrm{O}_{2}$ was added for 45 min to reveal peroxidase activity. After rinsing in Tris $0.05 \mathrm{M}$, sections were mounted and cover-slipped in Mowiol mounting medium. The number of Ki67-labeled cells revealed by DAB histochemistry was quantified with a bright-field microscope at $40 \mathrm{X}$ magnification, on a series of every sixth section at $300-\mu \mathrm{m}$ intervals spanning the entire hippocampus. Ki67-labeled cells were counted in the subgranular zone (SGZ), defined as a two-cell soma-wide zone along the base of the granule-cell layer. Cells were considered Ki67+ when their nuclei were completely filled with $\mathrm{DAB}$ product or showed patches of variable intensity. The number of Ki67+ cells per DG was estimated by multiplying the total number of cells by 6 (6 sections per series).

\subsection{Binding assays}

Mice were decapitated and brain regions, including the raphe nucleus, ventral tegmental area, dorsal striatum, and locus coeruleus were dissected on ice and homogenized with $25 \mathrm{ml}$ of ice cold buffer containing $50 \mathrm{mM}$ tris, $5 \mathrm{mM} \mathrm{MgCl} 2, \mathrm{pH} 7.4$. Homogenates were centrifuged for $20 \mathrm{~min}$ at $15000 \mathrm{x} \mathrm{g}$. The pellet was resuspended and centrifuged under the same condition three times. To the final suspension (0.2$0.6 \mathrm{mg} / \mathrm{ml})$ was added for one hour. $\left[{ }^{3} \mathrm{H}\right]$ nisoxetine $(21.3 \mathrm{Ci} / \mathrm{mmol}$; Perkin Elmer; USA) and $(1 \mathrm{nM}-10 \mu \mathrm{M})$ imipramine were used for NET binding. The process was terminated by immersing the tubes in ice cold buffer followed by rapid filtration through Whatman GF/B filters. Radioactivity was measured using liquid scintillation counting. Binding data were analyzed using the iterative non-linear fitting software GraphPad Prism 4.0 to estimate dissociation constants $\left(\mathrm{K}_{\mathrm{D}}\right)$ and maximum number of sites $\left(\mathrm{B}_{\max }\right)$.

\subsection{Antidepressant chronic treatment}

The effects of the SSRI antidepressants were evaluated on chronically stressed mice. Two groups of mice $(\mathrm{n}=5-6)$ of each genotype $\left(\mathrm{Htr}_{2 B}{ }^{+/+}\right.$and $\left.\mathrm{Htr}_{2 B}{ }^{-/-}\right)$received either vehicle (Veh) $(0.9 \% \mathrm{NaCl})$ Desipramine (Des) $(5 \mathrm{mg} / \mathrm{kg} /$ day; Sigma-Aldrich, Lyon, France) or Flx (3mg/kg/day; Biotrend, Switzerland) via i.p., once a day, beginning the fifth week of chronic isolation. The treatment continued for four extra weeks. The dose was chosen based on previous work from our laboratory (Diaz and Maroteaux, 2011; Diaz and Maroteaux, 2015). The forced swimming test (FST) was evaluated immediately after the first Flx, Des, or Veh administration, at the beginning of the $5^{\text {th }}$ week. Coat state and splash state were assessed at the end of the fourth week of treatment (week 8 of the experimental protocol). The novelty suppressed feeding (NSF) test was conducted the day after coat state and splash test evaluation. At the end of the eight weeks, mice were euthanized, perfused and brains were collected to study SGZ cell proliferation, as previously described. 


\subsection{Forced Swimming Test}

The FST was conducted essentially as described (Lucki et al., 2001). Briefly, swim sessions were conducted by placing mice individually in a plastic cylinder $(26 \mathrm{~cm}$ tall $\mathrm{x} 17 \mathrm{~cm}$ in diameter) filled with water $\left(24-27^{\circ} \mathrm{C}\right)$ to a depth of $15 \mathrm{~cm}$. A standard 6-min test duration was employed, and immobility time was only measured during the last 4 minutes of the test period. Mice were judged to be immobile when no additional activity was observed other than that required to keep their head above the water. After removing mice from water, they were dried and placed in their home cage. Each animal was challenged once. Injections were administered 30 minutes before the test session.

\subsection{Reagents}

Fluoxetine hydrochloride (Biotrend, Switzerland) or Desipramine hydrochloride (Sigma-Aldrich, Lyon, France) were dissolved in $0.9 \% \mathrm{NaCl}$. All the drugs were injected intraperitoneally (i.p.) in a volume of 0.1 $\mathrm{ml} / 10 \mathrm{~g}$ body weight of the animals.

\subsection{Statistical analysis}

To determine differences between the experimental groups, behavioral parameters and neuroplastic responses were analyzed by either an unpaired Student's t test or a two-factor analysis of variance (ANOVA) with genotypes and treatments as main factors depending on the experimental design. Bonferroni's test was used for post hoc comparisons. In all cases, $\mathrm{p}<0.05$ was considered statistically significant. A summary of statistical data, tests employed and statistics is presented in Table 1.

\section{RESULTS}

Statistical analysis of the presented data are summarized in Table 1.

\subsection{Characterization of the antidepressant-like phenotype in $\mathrm{Htr}_{2 B}{ }^{-/-}$mice}

An antidepressant-like phenotype can be described as the expression of a repertoire of signs similar to those induced by the chronic administration of antidepressants. The inhibition of feeding produced by exposure to a novel environment in the novelty suppressed feeding (NSF) test, is significantly shortened in mice submitted to a chronic treatment with antidepressants (Dulawa and Hen, 2005). As we have previously shown (Bevilacqua et al., 2010; Diaz et al., 2012), $\operatorname{ttr}_{2 B}{ }^{-/-}$mice exposed to the NSF test have a basal decreased latency to feed compared to $\mathrm{Htr}_{2 B}{ }^{+/+}$mice (Fig 1.a) supporting an antidepressant-like phenotype. After performing the NSF test, food consumption in the home cage was evaluated for each mouse during $15 \mathrm{~min}$. No significant differences were observed between genotypes (Fig 1.b), ruling out that the decreased latency to feed in mutant mice is due to altered appetite.

Even though human depressive symptoms are difficult to model in laboratory animals, there are some antidepressant-sensitive readouts correlated with anhedonia, a core symptom of clinical depression (Cryan and Mombereau, 2004). Decreased preference for sucrose consumption, particularly at low concentrations, has been extensively used as an anhedonia-like behavior in rats. In addition, this behavior is classically observed in mice chronically treated with antidepressants (Bechtholt et al., 2008). Therefore, we measured this parameter in mice having access to sucrose $2 \%$ or $8 \%$ plus water, and observed a significantly higher preference for sucrose $2 \%$ over tap water in $\mathrm{Htr}_{2 B}{ }^{-/-}$mice compared to $\mathrm{Htr}_{2 B}{ }^{+/+}$mice after habituation (Fig 1.c). These results are consistent with the fact that 129 mice strains display weaker preferences for sucrose solutions than other strains at low and intermediary concentrations.

It is well established that chronic antidepressant treatment increases the expression of the neurotrophin brain derived neurotrophic factor (BDNF) specifically in the hippocampus of rodents (Nibuya et al., 1995). We, thus, measured the expression of this neurotrophin and its receptors, TrkB and $\mathrm{p} 75$, in the hippocampus of $\mathrm{Htr}_{2 B}{ }^{-/-}$mice. A significant increase in $\mathrm{Bdnf}$ mRNA (Fig. 1.d) and protein levels (Fig. 1.e) was found in $\mathrm{Htr}_{2 B}{ }^{-/-}$mice compared to $\mathrm{Htr}_{2 B}{ }^{+/+}$mice, with no change in TrkB or p75 protein levels (Fig. 1.f-g). The basal increase in BDNF adds evidence in favor of an antidepressant-like phenotype for these mutant mice. 
Together, these changes in behavioral and biochemical parameters of mice lacking the 5- $\mathrm{HT}_{2 \mathrm{~B}}$ receptor gene are consistent with an antidepressant-like phenotype.

\section{2 $\mathrm{Htr}_{2 B}{ }^{-/}$mice exhibit no abnormal anxiogenic or anxiolytic behaviors}

Since $\operatorname{Htr}_{2 B}{ }^{-/}$mice exhibited behavior component (increased responsiveness to novelty) that could be interpreted as anxiety, we compared $\mathrm{Htr}_{2 B}{ }^{+/+}$and $\mathrm{Htr}_{2 B}{ }^{-/}$mice in open field and elevated plus maze paradigm. Actually, it has already been shown that anxiety could affect the locomotor pattern of animals (Navarro and Maldonado, 2002). It was therefore important to know if $\mathrm{Htr}_{2 B}{ }^{-/}$mice exhibit abnormal behaviors that could affect the interpretation of the results. Even though $\mathrm{Htr}_{2 B}{ }^{-/-}$mice travelled more in the peripheral area (PA), consistent with their reported novelty-induced locomotion (Doly et al., 2008), Htr $_{2 B}{ }^{-/}$, and $\mathrm{Htr}_{2 B}{ }^{+/+}$mice exhibited no significant difference in the distance travelled in center area (CA) of the open field (Fig. 2.a). The lack of difference in the locomotor activity displayed in the CA is relevant to interpret the NSF test, where mice have to reach food by travelling through the CA. To confirm this result, we compared $\mathrm{Htr}_{2 B}{ }^{-/}$, and $\mathrm{Htr}_{2 B}{ }^{+/+}$mice in a specific anxiety-like behavior paradigm, the elevated plus maze (Fig. 2.b). In this paradigm, anxious mice spend more time in the closed arms. $\mathrm{Htr}_{2 B}{ }^{-/-}$mice showed no significant difference compared to $\mathrm{Htr}_{2 B}{ }^{+/+}$mice.

Together, these results confirm that the genetic ablation of the $5-\mathrm{HT}_{2 \mathrm{~B}}$ receptor has no apparent effect on anxiety level of mice.

\subsection{Behavioral and neurobiological responses in $\mathrm{Htr}_{2 B}{ }^{-/-}$mice submitted to chronic isolation}

We then wondered if $\mathrm{Htr}_{2 B}{ }^{-/-}$mice displaying this antidepressant-like phenotype are able to develop a depressive-like state following a mild stress protocol consisting in chronic social isolation. We previously validated this protocol for 129S2/SvPas mice (Diaz and Maroteaux, 2015) by evaluating different behavioral and neurobiological parameters after chronic stress (coat state, splash test and hippocampus proliferation). The assessment of the coat state is a valid outcome to evaluate reduced self-care because stressed mice pay less attention to hygienic behaviors, and the fur get unkempt (Diaz and Maroteaux, 2015; Griebel et al., 2002; Santarelli et al., 2003). The coat score (Ibarguen-Vargas et al., 2008) significantly increased in both $\mathrm{Htr}_{2 B}{ }^{+/+}$and $\mathrm{Htr}_{2 B}{ }^{-/-}$mice after 4 weeks of chronic isolation (Fig. 3.a).

Chronic stress also diminishes the interest of mice in active grooming following squirting a sucrose solution on the dorsal coat as evaluated in the splash test (Yalcin et al., 2008). Compared to group-housed mice, the time spent doing grooming, recorded during a 5 minutes period, significantly decreased in both $\mathrm{Htr}_{2 B}{ }^{+/+}$and $\mathrm{Htr}_{2 B}{ }^{-/-}$mice after chronic isolation (Fig. 3.b).

Whereas the pro-neurogenic properties of antidepressants have been extensively demonstrated in the hippocampus of mice and humans, the role of cell proliferation in depressed patients or animal models is still unclear, for a review see (Petrik et al., 2012). Neurogenesis was evaluated in mice after 4 weeks of chronic isolation. A significant reduction in cell proliferation was observed in the SGZ of $\mathrm{Htr}_{2 B}{ }^{+/+}$mice compared to group-housed mice (Fig. 3.c). A marked trend to decrease was also observed in $\mathrm{Htr}_{2 B}{ }^{-/-}$mice that did not reach statistical significance, possibly due to the high variability in group-housed $\mathrm{Htr}_{2 B}{ }^{-/-}$mice. These behavioral and neurobiological outcomes suggest that the lack of 5- $\mathrm{HT}_{2 \mathrm{~B}}$ receptor does not prevent the development of a depressive-like state following chronic isolation, as demonstrated by the similar phenotype observed in both $\mathrm{Htr}_{2 B}{ }^{+/+}$mice and $\mathrm{Htr}_{2 B}{ }^{-/-}$mice.

\subsection{Antidepressant treatments of $\mathrm{Htr}_{2 B}{ }^{-/-}$mice submitted to chronic isolation}

We then investigated if changes observed after chronic stress can be reversed by antidepressant treatment. Previous results from our laboratory showed an absence of effect in non-stressed $\mathrm{Htr}_{2 B}{ }^{-/-}$mice receiving various SSRIs like fluoxetine, paroxetine (Diaz \& Maroteaux, 2011) or sertraline (unpublished results). Mice of either genotype chronically isolated during 4 weeks were immediately injected with antidepressant or vehicle. Behavioral and neurochemical assays were performed during the protocol as shown in Fig. 4a.

We previously reported (Diaz et al., 2012) by radioligand binding assays with the selective serotonin transporter (SERT) ligands on membranes prepared from raphe nucleus, that $\mathrm{Htr}_{2 B}{ }^{+/+}$and $\mathrm{Htr}_{2 B}{ }^{-/}$ mice express similar amount of SERT. Similarly, no differences in SERT immunofluorescence were found between genotypes in dorsal raphe (Diaz et al., 2012). To further document this issue, we performed 
additional in situ hybridization using a Sert probe showing no gross difference in mRNA expression between the two genotypes in raphe nuclei (Fig. 4b). To complete this study, we also performed radioligand-binding assays with the selective norepinephrine transporter (NET) ligands $\left[{ }^{3} \mathrm{H}\right] \mathrm{Nisoxetine}$ on membranes prepared from locus coeruleus or ventral tegmental area (VTA) and competed with desipramine showing no difference in NET expression between $H_{t r}{ }_{2 B}{ }^{+/+}$and $H t r_{2 B}{ }^{-/-}$mice (Fig. 4c-d). These data rule out differences in expression of NET or SERT in these mutant mice.

The effect of an acute administration of two antidepressants with different mechanisms of action was evaluated in the FST: the SSRI Flx and the norepinephrine selective reuptake inhibitor Desipramine (Des). A significant decrease of the immobility time was observed in $\mathrm{Htr}_{2 B}{ }^{+/+}$mice injected with either antidepressant. However, $\mathrm{Htr}_{2 B}{ }^{-/-}$mice displayed a significant decrease of the immobility time only in response to Des but not to Flx (Fig. 4e). These results confirmed that $\mathrm{Htr}_{2 B}{ }^{-/-}$mice are specifically impaired in responding to SSRIs but display classical responses to antidepressants of other pharmacological groups.

Then, we tested putative chronic effect of Flx after 4 weeks of chronic isolation. At the end of the $4^{\text {th }}$ week of Flx treatment, NSF, grooming, proliferation and coat state assays were performed. An effect of Flx revealed by a significant reduction in the latency to feed in the NSF test, was observed in $\mathrm{Htr}_{2 B}{ }^{+/+}$mice but not in $\operatorname{Htr}_{2 B}{ }^{-/-}$mice chronically treated with Flx (Fig. 5.a). Likewise, a significant increase in grooming time as measured in the splash test, was registered in stressed $\operatorname{Htr}_{2 B}{ }^{+/+}$mice but not in stressed $\mathrm{Htr}_{2 B}{ }^{-/-}$mice chronically treated with Flx (Fig. 5.b). As dorsal hippocampus is connected with cognitive functions, whereas the ventral part is more linked to stress, motion and affect (Fanselow and Dong, 2010; O'Leary and Cryan, 2014), we evaluated the effect of chronic Flx cell proliferation separately in dorsal and ventral hippocampus following chronic isolation. The chronic treatment with Flx induced a significant increase in cell proliferation in the SGZ as evaluated by Ki67 labeling in both the dorsal and the ventral part of the hippocampus of stressed $\mathrm{Htr}_{2 B}{ }^{+/+}$mice. However, no significant effect was observed in stressed $\mathrm{Htr}_{2 B}{ }^{-/-}$ mice (Fig. 5.c-d). Finally, the antidepressant Flx was neither able to improve the coat score in stressed $\mathrm{Htr}_{2 B}{ }^{+/+}$nor in $\mathrm{Htr}_{2 B}{ }^{-/-}$mice after 4 weeks of treatment (Fig. 5.e).

These results confirmed that, even after chronic mild stress, $\mathrm{Htr}_{2 B}{ }^{-/-}$mice do not respond to SSRI after acute or chronic injections. 


\section{DISCUSSION}

We further document herein the peculiar phenotype of $\mathrm{Htr}_{2 B}{ }^{-/-}$mice. In addition to the decreased latency to feed in NSF test, we identify here new specific behavioral and neurochemical parameters including a basal increase in hippocampal BDNF levels, with normal TrkB and $\mathrm{p} 75$ protein levels, and an increased preference for sucrose consumption. These three criteria can be considered as a baseline "antidepressantlike state" similar to features developed by animals exposed to antidepressant. Counterintuitively, we also found that this basal antidepressant-like phenotype does not protect $\mathrm{Htr}_{2 B}{ }^{-/-}$mice from a depressive-like state induced by a mild stress protocol consisting in chronic social isolation. We then show that the lack of 5-HT $2 \mathrm{~B}$ receptors prevents $\mathrm{Htr}_{2 B}{ }^{-/-}$mice from responding specifically to the SSRI Flx in acute or chronic injections after chronic mild stress.

Recent studies have reported various mice lines that display an antidepressant-like phenotype based on single parameter. For example, pharmacological inhibition of the phospholipase $\mathrm{C}$ - protein kinase $\mathrm{C}$ cascade in mice induced a significant decrease of immobility time in the FST, interpreted as an antidepressant-like response (Galeotti and Ghelardini, 2011). Likewise, antidepressant-like behaviors, as measured by the FST and the tail suspension test (TST), have been observed in mice with different levels of 5- $\mathrm{HT}_{2 \mathrm{C}}$ receptor mRNA editing (Mombereau et al., 2010). Three independent criteria were employed in our study to analyze the antidepressant-like phenotype. First, antidepressants of different pharmacological groups are known to increase the expression of the neurotrophin BDNF in the hippocampus (Nibuya et al., 1995). It has been suggested that this increase is necessary for neurogenic effects of antidepressants, but more thorough studies are needed to be conclusive. As BDNF is secreted as a pro-neurotrophin, which is cleaved to generate mature BDNF (m-BDNF), further expression analysis of both isoforms pro- and mBDNF could shed light on how they participate in antidepressant effects. Similarly, given the lack of difference in expression of TrkB and $\mathrm{p} 75$, the pro- and $\mathrm{m}$-BDNF receptors, respectively, it could be interesting to study if activation of TrkB receptor is modified in $H_{t r}{ }_{2 B}^{-1-}$ mice with high hippocampal BDNF. A second characteristic of antidepressant-treated rodents is their preference for sweetened solutions. Laboratory mice strain "129" are well known for being sweet subsensitive mice compared to sensitive C57Bl/6 mice (Sclafani, 2006) likely due to allelic variations. As expected, 129S2 mice evaluated here display a moderate preference for sucrose (around 60\%) over water, but still we were able to see a significant increased sucrose preference in $\mathrm{Htr}_{2 B}{ }^{-/-}$mice. Finally, a decreased latency to feed in the NSF test has been already demonstrated (Diaz et al., 2012). Even though $\mathrm{Htr}_{2 B}{ }^{-/-}$mice display an impulsive phenotype (Bevilacqua et al., 2010), we rule out here that modified locomotor activity or appetite could affect their response to NSF test. All in all, using a combination of three independent informations, (i) increased hippocampal BDNF levels and normal TrkB and p75 expression, (ii) a significant preference for sucrose consumption, and (iii) a decreased latency to feed in the NSF test, we report now that tr $_{2 B}{ }^{-/-}$mice display a basal phenotype comparable to animals chronically treated with antidepressants or "antidepressant-like phenotype".

Depression is one of the diseases that has been exhaustively studied although several questions remain opened around its ethiopathology and treatment (Lee et al., 2010). Antidepressant effects evaluated in "normal" mice may engage different neurobiological mechanisms than those involved in the response of "depressed" animals (Cryan et al., 2002). Depressive-like symptoms in animals are not easy to model since many clinical signs of depression are difficult or even impossible to evaluate in animals, such as guiltiness or suicidal ideation (Cryan and Holmes, 2005). In this respect, measures of anhedonic behaviors like decreased preference for sucrose consumption or reduced interest for hygienic habits are preferred outcomes as they might be indicative of depressive-like behaviors. Additionally, when describing a depressive-like phenotype in animals, the evaluation of several signs rather than single behavioral parameters adds consistency to conclusions. We previously reported that the behavior developed by $129 \mathrm{~S} 2$ mice subjected to UCMS is more dramatic than in other mice strains. We thus, proposed chronic social isolation as a milder and more appropriate stress paradigm for 129S2 strains (Diaz and Maroteaux, 2015). We now evaluated two behavioral parameters (i.e. coat score \& splash test) plus an histologic outcome (DG cell proliferation) to characterize the depressive-like state induced by chronic stress and found almost similar outcomes in both $\mathrm{Htr}_{2 B}{ }^{-/-}$and $\mathrm{Htr}_{2 B}{ }^{+/+}$mice subjected to chronic social isolation. The present results indicate that the baseline "antidepressant-like state" associated to the lack of 5-HT $2 \mathrm{~B}$ receptors does not 
prevent the vulnerability to develop a depressive-like state following chronic stress. In other words, the 5$\mathrm{HT}_{2 \mathrm{~B}}$ receptor does not appear to participate in the establishment of stress-induced depressive state, whereas it has a key role in the effects of serotonergic antidepressant. Similar dichotomies have been suggested for other aspect linked to antidepressants. For example, while neurogenesis appears necessary for antidepressant effects (Malberg et al., 2000), it is not clear if defects in neurogenesis play a role in depression (Petrik et al., 2012). These controversies ensure further studies to understand the ethiopathology of depression. Furthermore, it supports the idea that antidepressants do not necessarily target the causative factors triggering depression.

Following chronic stress, we were able to show that acute antidepressant effects in FST are retained in both $\mathrm{Htr}_{2 B}{ }^{+/+}$and $\mathrm{Htr}_{2 B}{ }^{-/-}$mice for Des; however, Flx was only efficient in $\mathrm{Htr}_{2 B}{ }^{+/+}$mice, further supporting the specific alteration of the serotonergic system in these mice. In addition, parameters altered after chronic isolation can be reversed by Flx only in $\operatorname{Htr}_{2 B}{ }^{+/+}$mice but not in $\mathrm{Htr}_{2 B}{ }^{-/-}$mice, including the increase in time of grooming in the splash test, and the decrease in latency to feed in the NSF test. Cell proliferation in the DG cell layer is a correlate of chronic treatment with antidepressants originally described in rats (Malberg et al., 2000) and later extended to mice (Santarelli et al., 2003). We observed a significant increase in both dorsal and ventral hippocampus SGZ proliferation after chronic isolation and treatment with Flx in $\mathrm{Htr}_{2 B}{ }^{+/+}$mice but not in $\mathrm{Htr}_{2 B}{ }^{-/-}$mice. These findings correlate with previous observations made in non-stressed $\mathrm{Htr}_{2 B}{ }^{-/-}$mice (Diaz et al., 2012; Diaz and Maroteaux, 2011). From a work on astrocytes, it has been suggested that fluoxetine and other SSRIs could be acting as direct 5-HT $2 \mathrm{~B}$ receptor agonists independently of the serotonin transporter (SERT) (Hertz et al., 2015). Previous data from our group (Diaz et al., 2012) do not support this hypothesis since we reported the absence of antidepressant effects of fluoxetine in mice lacking either the serotonin transporter (knockout for SERT$\mathrm{Sert}^{-/}$) or differentiated serotonin neurons (knockout for Pet1-Pet $1^{--}$). This rules out that the antidepressant effects of fluoxetine could be independent of SERT, and indicates that serotonin neurons expressing SERT (and 5- $\mathrm{HT}_{2 \mathrm{~B}}$ receptors) are necessary for the 5- $\mathrm{HT}_{2 \mathrm{~B}}$ receptor effects independently of other cell types. This also rules out the possibility that SSRIs mediate antidepressant effects only by stimulating directly putative astrocytic 5-HT $2 \mathrm{~B}$ receptors, which should be intact in these two mutant mice (Sert ${ }^{-/}$and $\mathrm{Pet1}^{-/-}$) (Banas et al., 2015). Furthermore, our pharmacological determination in mice is in accordance with affinity of SSRIs for human 5-HT $2 \mathrm{~B}$ receptors with Ki values over $5 \mu \mathrm{M}$ (Diaz et al., 2012), while SSRI Ki values for SERT are in nanomolar range. Finally, the published evidence for $5-\mathrm{HT}_{2 \mathrm{~B}}$ receptor expression in microglia (Kolodziejczak et al., 2015; Krabbe et al., 2012) add another level of complexity, as the concept of the tripartite synapse has recently been expanded to the monoaminergic systems to explain antidepressant drug responses (Quesseveur et al., 2013). A full set of research is thus needed to understand the putative role for serotonin in glial cells including astrocytes and/or microglia with respect to the relationship between SSRIs, serotonergic neurons and 5- $\mathrm{HT}_{2 \mathrm{~B}}$ receptors.

Our findings indicate that increased BDNF levels observed in the hippocampus of $\mathrm{Htr}_{2 B}{ }^{-/-}$mice do not dampen the stress response to chronic social isolation. Mice heterozygous for $B d n f$ have been proposed as a mouse model of genetic resistance to antidepressants, since $B d n f^{+/}$mice do not respond to antidepressant neither in the FST (Monteggia et al., 2004; Saarelainen et al., 2003) nor in the cell proliferation assay (Sairanen et al., 2005). In these $B d n f^{+/}$mice, hippocampal extracellular serotonin levels do not increase after acute paroxetine administration (Deltheil et al., 2008) as it is the case for $\operatorname{Htr}_{2 B}{ }^{-/-}$mice (Diaz et al., 2012; Diaz and Maroteaux, 2011). These results suggest that altered levels of BDNF impair the actions of antidepressants even though the underlying causes are still unknown. After a report showing an increase of BDNF expression in the hippocampus of rats chronically treated with antidepressants (Nibuya et al., 1995), several studies confirmed these results in rodents (Malberg et al., 2000; Russo-Neustadt et al., 2004; Tsankova et al., 2006), suggesting that increased levels of this neurotrophin could protect neurons from the noxious effects of stress. Further, antidepressant effects were reproduced in rats by infusing BDNF in the midbrain (Siuciak et al., 1997) or the hippocampus (Shirayama et al., 2002). In contrast, the role of this neurotrophin in the ethiopathogeny of depression is less studied. The increased BDNF in the $H_{t r}{ }_{2 B}{ }^{-/-}$mice could be at least partially responsible for the lack of antidepressant effect of Flx in these mutant mice. Considering that an intact BDNF pathway is required for antidepressant effect, the altered basal BDNF levels observed in the hippocampus of $\mathrm{Htr}_{2 B}{ }^{-/-}$mice could be a causative factor for the absence 
of Flx effects in stressed $\operatorname{Htr}_{2 B}{ }^{-/-}$mice as shown here, and in naive $\mathrm{Htr}_{2 B}{ }^{-/-}$mice (Diaz et al., 2012; Diaz and Maroteaux, 2011). Our results are in agreement with a study conducted in $B d n f^{+/-}$mice in which the altered levels of BDNF attenuate the effect of antidepressants in the resident/intruder test and the TST but do not affect vulnerability to UCMS-induced stress (Ibarguen-Vargas et al., 2009). Indeed, it was suggested that there is no simple link between depressive-like behaviors and hippocampal BDNF levels (Larsen et al., 2010). Together, these findings may explain why altered hippocampal BDNF levels, as it is the case for $\mathrm{Htr}_{2 B}{ }^{-/-}$mice, do not prevent the development of the depressive-like state after chronic isolation. These results reinforce the idea that whereas BDNF and neurogenic processes are required for the actions of antidepressants, their participation in the ethiopathogeny of depression is less consistent (Ibarguen-Vargas et al., 2009; Petrik et al., 2012).

Mouse models displaying an antidepressant-like phenotype, are convenient for studying resistance to antidepressants, a highly prevalent health problem reported, for example, in fifty-five per cent of the patients in a multicenter randomized controlled trial conducted in UK (Thomas et al., 2013). The results we present herein enhance the relevance of $\mathrm{Htr}_{2 B}{ }^{-/-}$mice as a model of resistance to SSRIs. These mice do not respond to acute or chronic SSRIs treatment even after chronic isolation. As a high proportion of clinical patients do not respond to classical pharmacotherapies, animal models of resistance to antidepressants are required to more thoroughly study the underlying neurobiological causes of this process and to develop new pharmacological targets. The experiments conducted by our laboratory describe $H_{t r}{ }_{2 B}^{-/-}$mice as a useful tool to explore neurochemical and molecular basis of resistance to SSRI antidepressant, one major unsolved problem in clinical treatment of depression. 


\section{Role of Funding Source.}

Funding for this study was provided by the Centre National de la Recherche Scientifique, the Institut National de la Santé et de la Recherche Médicale, the Université Pierre et Marie Curie, and by grants from the Fondation pour la Recherche sur le Cerveau, the Fondation pour la Recherche Médicale "Equipe FRM DEQ2014039529", the French Ministry of Research (Agence Nationale pour la Recherche ANR-12BSV1-0015-01 and the Investissements d'Avenir programme ANR-11-IDEX-0004-02). LM's team is part of the École des Neurosciences de Paris Ile-de-France network and of the Bio-Psy Labex. S. Diaz has been supported by fellowships from IBRO and then from Region Ile de France DIM STEM. None of these founding agencies had further role in study design, in the collection, analysis and interpretation of data, in the writing of the report, and in the decision to submit the paper for publication.

\section{Contributors}

SLD, LM designed the study; KB and NNN, performed in situ hybridization; SLD, KB, SD performed mice injection and care, immunohistochemistry and behavioral studies; SLD and LM undertook the statistical analysis; SLD wrote the first draft of the manuscript; NNN, SD and LM corrected the draft. All authors contributed to and have approved the final manuscript.

\section{Conflict of Interest}

All authors disclose any commercial affiliations as well as consultancies, stock or equity interests, and patent-licensing arrangements that could be considered a conflict of interest. The authors declare no conflict of interest.

\section{Acknowledgements}

We thank Dr.Noriyuki Koibuchi, from the Gunma University Graduate School of Medicine in Japan, for kindly sending us the BDNF probe. 


\section{REFERENCES}

Bally-Cuif, L., Wassef, M., 1994. Ectopic induction and reorganization of Wnt-1 expression in quail/chick chimeras. Development 120, 3379-3394.

Banas, S.M., Diaz, S.L., Doly, S., Belmer, A., Maroteaux, L., 2015. Commentary: Chronic SSRI stimulation of astrocytic 5-HT2B receptors change multiple gene expressions/editings and metabolism of glutamate, glucose and glycogen: a potential paradigm shift. Frontiers in Behavioral Neuroscience 9, $1-3$.

Bechtholt, A.J., Smith, K., Gaughan, S., Lucki, I., 2008. Sucrose intake and fasting glucose levels in 5HT(1A) and 5-HT(1B) receptor mutant mice. Physiol Behav 93, 659-665.

Bevilacqua, L., Doly, S., Kaprio, J., Yuan, Q., Tikkanen, R., Paunio, T., Zhou, Z., Wedenoja, J., Maroteaux, L., Diaz, S., Belmer, A., Hodgkinson, C., Dell'Osso, L., Suvisaari, J., Coccaro, E., Rose, R., Peltonen, L., Virkkunen, M., Goldman, D., 2010. A population-specific HTR2B stop codon predisposes to severe impulsivity. Nature 468, 1061-1066.

Blazer, D.G., 2nd, Hybels, C.F., 2005. Origins of depression in later life. Psychol Med 35, 1241-1252.

Cryan, J.F., Holmes, A., 2005. The ascent of mouse: advances in modelling human depression and anxiety. Nat Rev Drug Discov 4, 775-790.

Cryan, J.F., Markou, A., Lucki, I., 2002. Assessing antidepressant activity in rodents: recent developments and future needs. Trends Pharmacol Sci 23, 238-245.

Cryan, J.F., Mombereau, C., 2004. In search of a depressed mouse: utility of models for studying depression-related behavior in genetically modified mice. Mol Psychiatry 9, 326-357.

Deltheil, T., Guiard, B.P., Cerdan, J., David, D.J., Tanaka, K.F., Reperant, C., Guilloux, J.P., Coudore, F., Hen, R., Gardier, A.M., 2008. Behavioral and serotonergic consequences of decreasing or increasing hippocampus brain-derived neurotrophic factor protein levels in mice. Neuropharmacology 55, 10061014.

Diaz, S.L., Doly, S., Narboux-Nême, N., Fernandez, S., Mazot, P., Banas, S., Boutourlinsky, K., Moutkine, I., Belmer, A., Roumier, A., Maroteaux, L., 2012. 5-HT2B receptors are required for serotonin-selective antidepressant actions. Mol Psychiatry 17, 154-163.

Diaz, S.L., Maroteaux, L., 2011. Implication of 5-HT2B receptors in the serotonin syndrome. Neuropharmacology 61, 495-502.

Diaz, S.L., Maroteaux, L., 2015. Dissecting a model of depressive-related phenotype and antidepressants effects in 129S2/SvPas mice, in: Blenau, W., Baumann, A. (Eds.), Serotonin Receptor Technologies. Humana Press, pp. 59-82.

Doly, S., Valjent, E., Setola, V., Callebert, J., Herve, D., Launay, J.M., Maroteaux, L., 2008. Serotonin 5HT2B receptors are required for 3,4-methylenedioxymethamphetamine-induced hyperlocomotion and 5HT release in vivo and in vitro. J Neurosci 28, 2933-2940.

Ducottet, C., Aubert, A., Belzung, C., 2004. Susceptibility to subchronic unpredictable stress is related to individual reactivity to threat stimuli in mice. Behav Brain Res 155, 291-299.

Dulawa, S.C., Hen, R., 2005. Recent advances in animal models of chronic antidepressant effects: the novelty-induced hypophagia test. Neurosci Biobehav Rev 29, 771-783.

Fanselow, M.S., Dong, H.-W., 2010. Are the dorsal and ventral hippocampus functionally distinct structures? Neuron 65, 7-19.

Galeotti, N., Ghelardini, C., 2011. Antidepressant phenotype by inhibiting the phospholipase Cbeta(1)-protein kinase Cgamma pathway in the forced swim test. Neuropharmacology 60, 937-943.

Griebel, G., Simiand, J., Serradeil-Le Gal, C., Wagnon, J., Pascal, M., Scatton, B., Maffrand, J.P., Soubrie, P., 2002. Anxiolytic- and antidepressant-like effects of the non-peptide vasopressin V1b receptor antagonist, SSR149415, suggest an innovative approach for the treatment of stress-related disorders. Proc Natl Acad Sci U S A 99, 6370-6375.

Hertz, L., Rothman, D.L., Li, B., Peng, L., 2015. Chronic SSRI stimulation of astrocytic 5-HT2B receptors change multiple gene expressions/editings and metabolism of glutamate, glucose and glycogen: a potential paradigm shift. Front Behav Neurosci 9, 25. 
Ibarguen-Vargas, Y., Surget, A., Touma, C., Palme, R., Belzung, C., 2008. Multifaceted strain-specific effects in a mouse model of depression and of antidepressant reversal. Psychoneuroendocrinology 33, 1357-1368.

Ibarguen-Vargas, Y., Surget, A., Vourc'h, P., Leman, S., Andres, C.R., Gardier, A.M., Belzung, C., 2009. Deficit in BDNF does not increase vulnerability to stress but dampens antidepressant-like effects in the unpredictable chronic mild stress. Behav Brain Res 202, 245-251.

Kolodziejczak, M., Bechade, C., Gervasi, N., Irinopoulou, T., Banas, S.M., Cordier, C., Rebsam, A., Roumier, A., Maroteaux, L., 2015. Serotonin Modulates Developmental Microglia via 5-HT2B Receptors: Potential Implication during Synaptic Refinement of Retinogeniculate Projections. ACS Chem Neurosci 6, 1219-1230.

Krabbe, G., Matyash, V., Pannasch, U., Mamer, L., Boddeke, H.W.G.M., Kettenmann, H., 2012. Activation of serotonin receptors promotes microglial injury-induced motility but attenuates phagocytic activity. Brain Behav Immun 26, 419-428.

Kupfer, D.J., Frank, E., Phillips, M.L., 2012. Major depressive disorder: new clinical, neurobiological, and treatment perspectives. Lancet 379, 1045-1055.

Larsen, M.H., Mikkelsen, J.D., Hay-Schmidt, A., Sandi, C., 2010. Regulation of brain-derived neurotrophic factor (BDNF) in the chronic unpredictable stress rat model and the effects of chronic antidepressant treatment. J Psychiatr Res 44, 808-816.

Lucki, I., Dalvi, A., Mayorga, A.J., 2001. Sensitivity to the effects of pharmacologically selective antidepressants in different strains of mice. Psychopharmacology (Berl) 155, 315-322.

Malberg, J.E., Eisch, A.J., Nestler, E.J., Duman, R.S., 2000. Chronic antidepressant treatment increases neurogenesis in adult rat hippocampus. J Neurosci 20, 9104-9110.

Mombereau, C., Kawahara, Y., Gundersen, B.B., Nishikura, K., Blendy, J.A., 2010. Functional relevance of serotonin 2C receptor mRNA editing in antidepressant- and anxiety-like behaviors. Neuropharmacology 59, 468-473.

Monteggia, L.M., Barrot, M., Powell, C.M., Berton, O., Galanis, V., Gemelli, T., Meuth, S., Nagy, A., Greene, R.W., Nestler, E.J., 2004. Essential role of brain-derived neurotrophic factor in adult hippocampal function. Proc Natl Acad Sci U S A 101, 10827-10832.

Navarro, J.F., Maldonado, E., 2002. Acute and subchronic effects of MDMA ("ecstasy") on anxiety in male mice tested in the elevated plus-maze. Prog Neuropsychopharmacol Biol Psychiatry 26, 1151-1154.

Nibuya, M., Morinobu, S., Duman, R.S., 1995. Regulation of BDNF and trkB mRNA in rat brain by chronic electroconvulsive seizure and antidepressant drug treatments. J Neurosci 15, 7539-7547.

O'Leary, O.F., Cryan, J.F., 2014. A ventral view on antidepressant action: roles for adult hippocampal neurogenesis along the dorsoventral axis. Trends Pharmacol Sci 35, 675-687.

Petrik, D., Lagace, D.C., Eisch, A.J., 2012. The neurogenesis hypothesis of affective and anxiety disorders: are we mistaking the scaffolding for the building? Neuropharmacology 62, 21-34.

Quesseveur, G., Gardier, A.M., Guiard, B.P., 2013. The monoaminergic tripartite synapse: a putative target for currently available antidepressant drugs. Curr Drug Targets 14, 1277-1294.

Russo-Neustadt, A.A., Alejandre, H., Garcia, C., Ivy, A.S., Chen, M.J., 2004. Hippocampal brain-derived neurotrophic factor expression following treatment with reboxetine, citalopram, and physical exercise. Neuropsychopharmacology 29, 2189-2199.

Saarelainen, T., Hendolin, P., Lucas, G., Koponen, E., Sairanen, M., MacDonald, E., Agerman, K., Haapasalo, A., Nawa, H., Aloyz, R., Ernfors, P., Castren, E., 2003. Activation of the TrkB neurotrophin receptor is induced by antidepressant drugs and is required for antidepressant-induced behavioral effects. J Neurosci 23, 349-357.

Sairanen, M., Lucas, G., Ernfors, P., Castrén, M., Castrén, E., 2005. Brain-derived neurotrophic factor and antidepressant drugs have different but coordinated effects on neuronal turnover, proliferation, and survival in the adult dentate gyrus. J Neurosci 25, 1089-1094.

Santarelli, L., Saxe, M., Gross, C., Surget, A., Battaglia, F., Dulawa, S., Weisstaub, N., Lee, J., Duman, R., Arancio, O., Belzung, C., Hen, R., 2003. Requirement of hippocampal neurogenesis for the behavioral effects of antidepressants. Science 301, 805-809. 
Sclafani, A., 2006. Sucrose motivation in sweet "sensitive" (C57BL/6J) and "subsensitive" (129P3/J) mice measured by progressive ratio licking. Physiology \& behavior 87, 734-744.

Shirayama, Y., Chen, A.C., Nakagawa, S., Russell, D.S., Duman, R.S., 2002. Brain-derived neurotrophic factor produces antidepressant effects in behavioral models of depression. J Neurosci 22, 3251-3261.

Siuciak, J.A., Lewis, D.R., Wiegand, S.J., Lindsay, R.M., 1997. Antidepressant-like effect of brain-derived neurotrophic factor (BDNF). Pharmacol Biochem Behav 56, 131-137.

Southwick, S.M., Charney, D.S., 2012. The science of resilience: implications for the prevention and treatment of depression. Science 338, 79-82.

Thomas, L., Kessler, D., Campbell, J., Morrison, J., Peters, T.J., Williams, C., Lewis, G., Wiles, N., 2013. Prevalence of treatment-resistant depression in primary care: cross-sectional data. Br J Gen Pract 63, e852-858.

Tsankova, N.M., Berton, O., Renthal, W., Kumar, A., Neve, R.L., Nestler, E.J., 2006. Sustained hippocampal chromatin regulation in a mouse model of depression and antidepressant action. Nat Neurosci 9, 519-525.

Willner, P., Muscat, R., Papp, M., 1992. Chronic mild stress-induced anhedonia: a realistic animal model of depression. Neurosci Biobehav Rev 16, 525-534.

Yalcin, I., Belzung, C., Surget, A., 2008. Mouse strain differences in the unpredictable chronic mild stress: a four-antidepressant survey. Behav Brain Res 193, 140-143. 


\section{Figure 1}
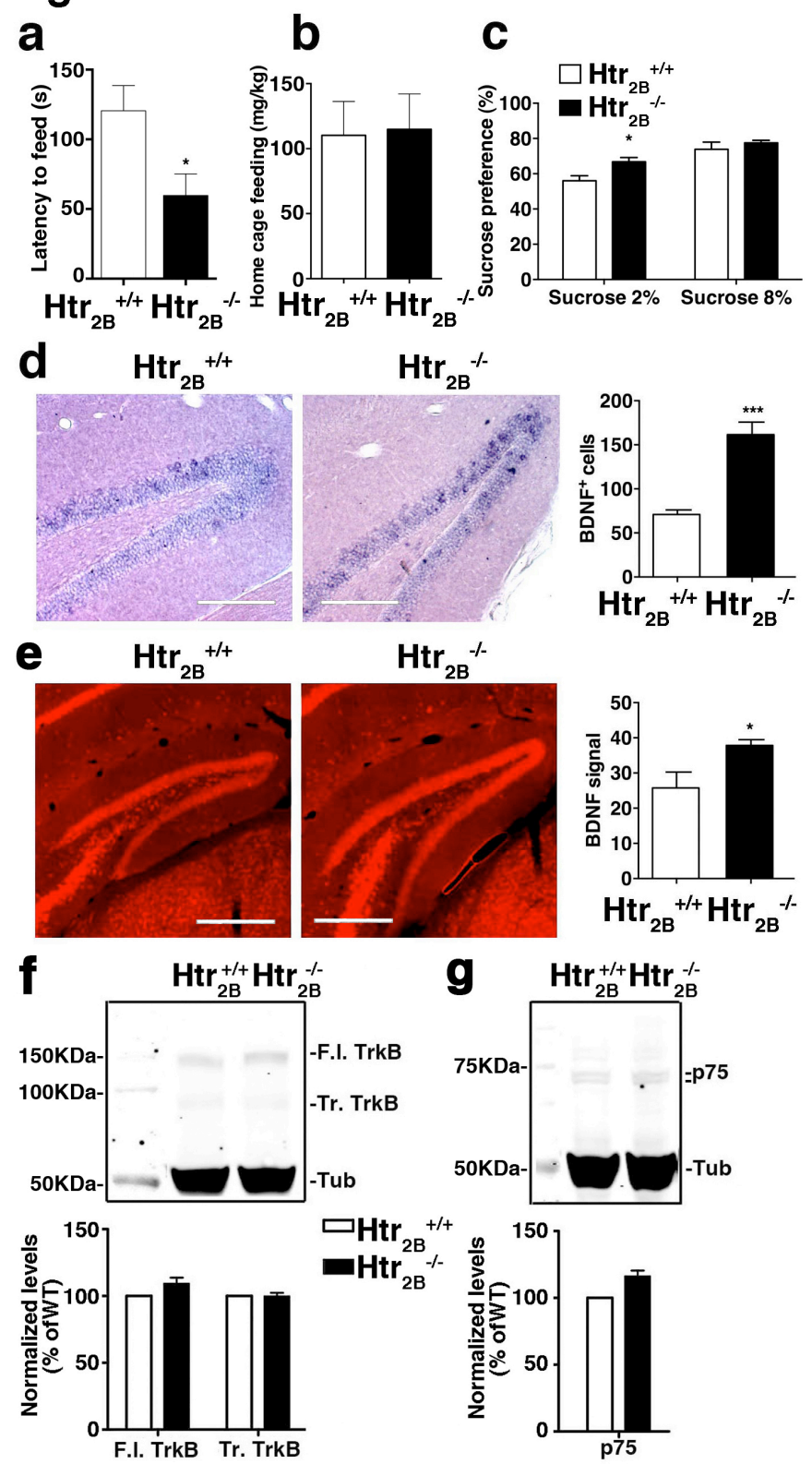

Figure 1. Antidepressant-like phenotype in $\mathrm{Htr}_{2 B}{ }^{-/-}$mice.

(a) In the NSF test, basal latency to feed was significantly reduced in $\mathrm{Htr}_{2 B}{ }^{-/-}$compared to $\mathrm{Htr}_{2 B}{ }^{+/+}$mice. (b) After performing the NSF test, food consumption in the home cage was evaluated for each mouse during 15 min. No significant differences were observed between genotypes or treatments. (c) Sucrose preference expressed as the percentage of sucrose consumption $(\mathrm{ml} / \mathrm{kg}$ ) over the total consumption (sucrose + water; $\mathrm{ml} / \mathrm{kg}$ ) during $24 \mathrm{~h}$ was significantly higher in $\mathrm{Htr}_{2 B}{ }^{-/-}$mice compared to $\mathrm{Htr}_{2 B}{ }^{+/+}$mice only at low sucrose concentration (2\%). (d) Bdnf mRNA levels in the Dentate Gyrus (DG) determined by in situ hybridization doubled in $\operatorname{Htr}_{2 B}{ }^{-/-}$mice compared to $\operatorname{Htr}_{2 B}{ }^{+/+}$mice. Representative $B d n f$ mRNA labeling in the DG of $H_{t r}{ }_{2 B}{ }^{+/+}$and $H_{t r}{ }_{2 B}{ }^{-/-}$mice (scale bar, $50 \mu \mathrm{m}$ ) with quantification (right). (e) BDNF protein levels in the DG as measured by immunofluorescence after subtraction of background signal was significantly higher in $\mathrm{Htr}_{2 B}{ }^{-/-}$mice compared to $\mathrm{Htr}_{2 B}{ }^{+/+}$mice. Representative BDNF immunolabeling in the brain of $\mathrm{Htr}_{2 B}{ }^{+/+}$and $H t r_{2 B}{ }^{-/-}$mice (scale bar, $50 \mu \mathrm{m}$ ) with quantification (right). Basal levels of BDNF receptors TrkB full lengths (F.1.) and truncated (Tr.) forms (f) and p75 (g) were similar in $\mathrm{Htr}_{2 B}{ }^{+/+}$and $\mathrm{Htr}_{2 B}{ }^{-/-}$mice.

Representative blots for hippocampal TrkB and p75 protein levels in either genotype are shown with tubulin expression as internal control and quantification below. Data are expressed as mean $\pm \mathrm{SEM} ; \mathrm{n}=5-6$ (a, d, e, f, g), 8-13 (c), $\mathrm{n}=4-5$ (b) mice for each group); Student's t test; *** $\mathrm{p}<0,001 ; * \mathrm{p}<0.05$ comparing to $\mathrm{Htr}_{2 B}{ }^{+/+}$mice. 


\section{Figure 2}
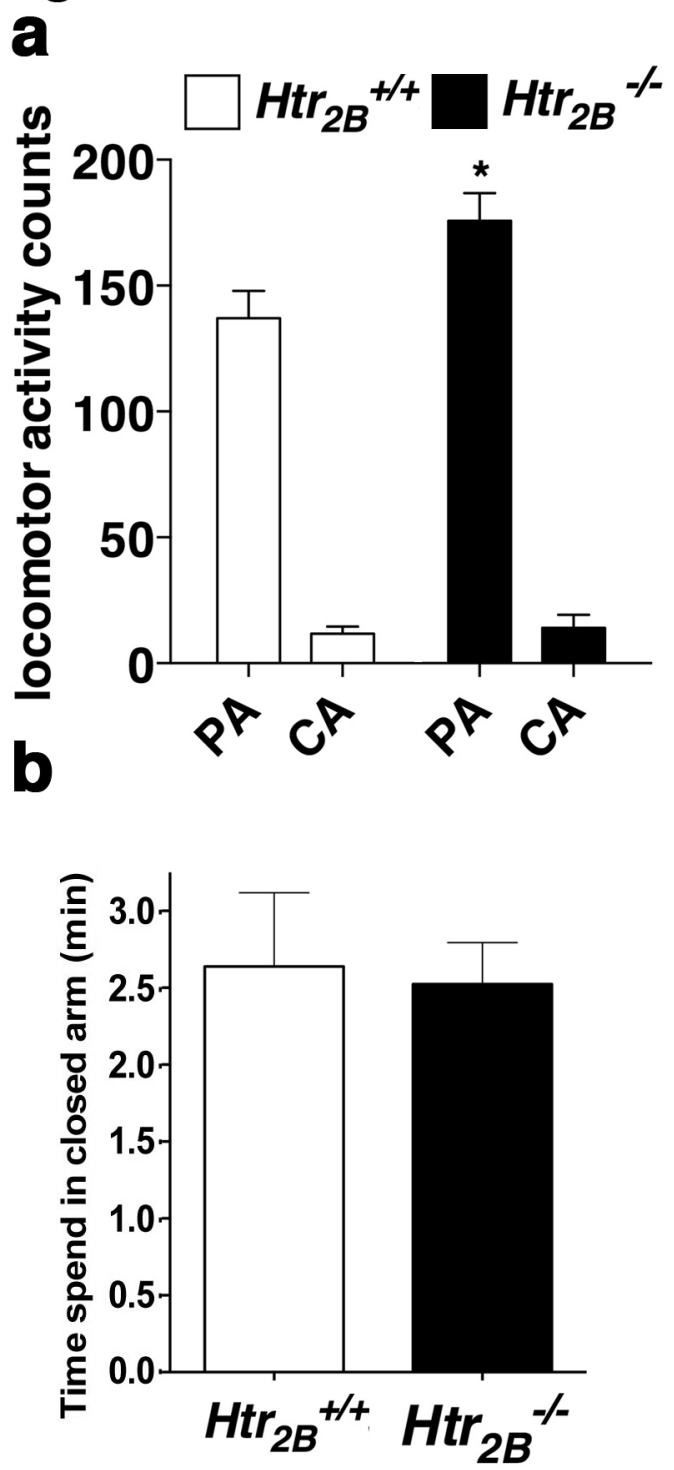

Figure 2: $\mathrm{Htr}_{2 B}{ }^{-/-}$or $\mathrm{Htr}_{2 B}{ }^{+/+}$mice exhibit no difference in anxiogenic or anxiolytic behaviors. (a) Locomotor activity counts represent the number of square $(14 \times 14 \mathrm{~cm})$ crossed in periphery (PA) or center (CA) area of the open field by each mouse during 9 min. Data (means \pm SEM), were analyzed using unpaired t test (two tailed): $\mathrm{n}=10$ per group; * $H_{t r}{ }_{2 B}{ }^{+/+}$versus $\operatorname{Htr}_{2 B}{ }^{-/-}$mice. (b) Time spend in the closed arms of elevated plus maze for $\mathrm{Htr}_{2 B}{ }^{+/+}$and $\mathrm{Htr}_{2 B}{ }^{-/-}$mice. Data (means $\pm \mathrm{SEM}$ ), were analyzed ( $\mathrm{n}=10$ per group) using unpaired t test (two tailed). No significant differences were seen. 


\section{Figure 3}
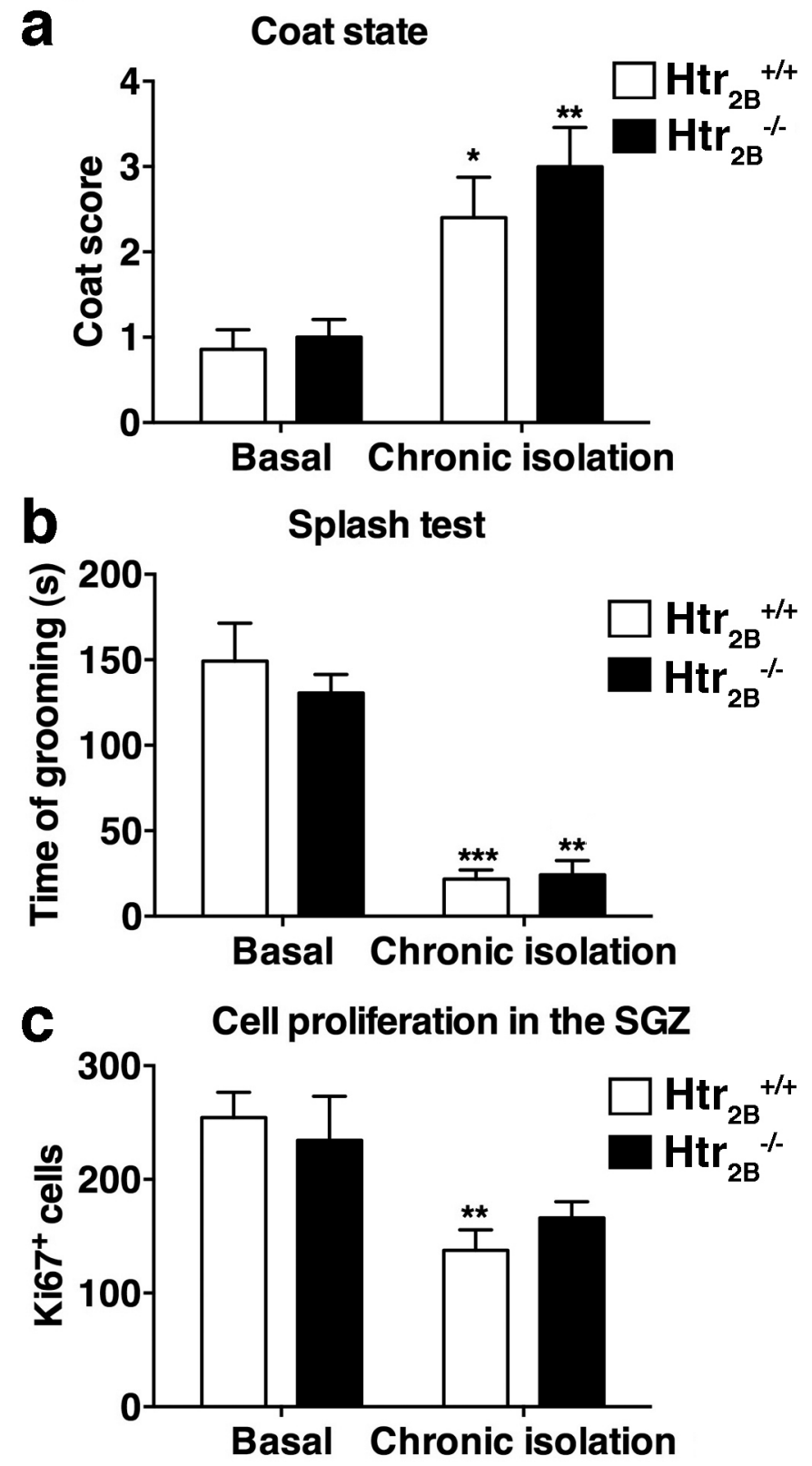

Figure 3. Effects of Social Chronic Isolation. (a) The state of the coat was evaluated in $\operatorname{Htr}_{2 B}{ }^{+/+}$and $\operatorname{Htr}_{2 B}{ }^{-/-}$mice, and the score significantly increased in both genotypes after chronic isolation. (b) The time spent grooming in the Splash test was measured in $\mathrm{Htr}_{2 B}{ }^{+/+}$and $\mathrm{Htr}_{2 B}{ }^{-/-}$mice and a significant decrease was observed in both genotypes after chronic isolation. (c) DG cell proliferation in the subgranular zone (SGZ) as measured by Ki67 labeling was significantly decreased in $\operatorname{Htr}_{2 B}{ }^{+/+}$mice after chronic isolation, and the trend for a decrease in $\mathrm{Htr}_{2 B}{ }^{-{ }_{-}}$mice did not reach significance. Data are expressed as mean \pm SEM $(\mathrm{n}=9$ 10 mice for each group) and were analyzed by Two-way ANOVA followed by Bonferroni post-hoc test; $* * * \mathrm{p}<0.001 ; * * \mathrm{p}<0.01 ; * \mathrm{p}<0.05$. 
a

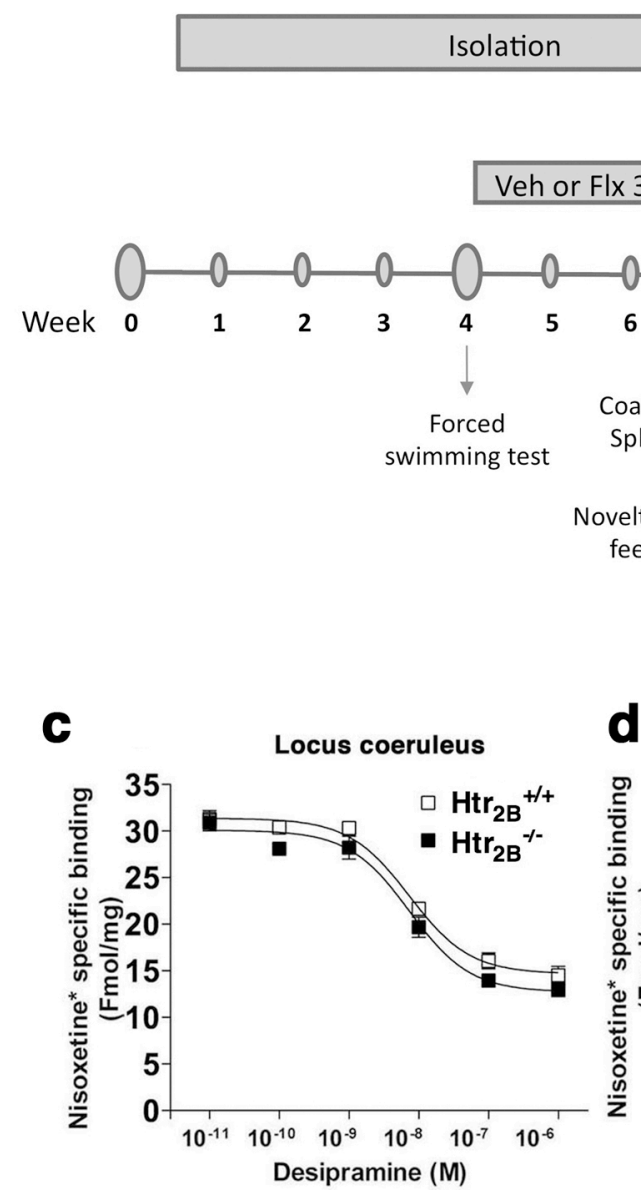

b

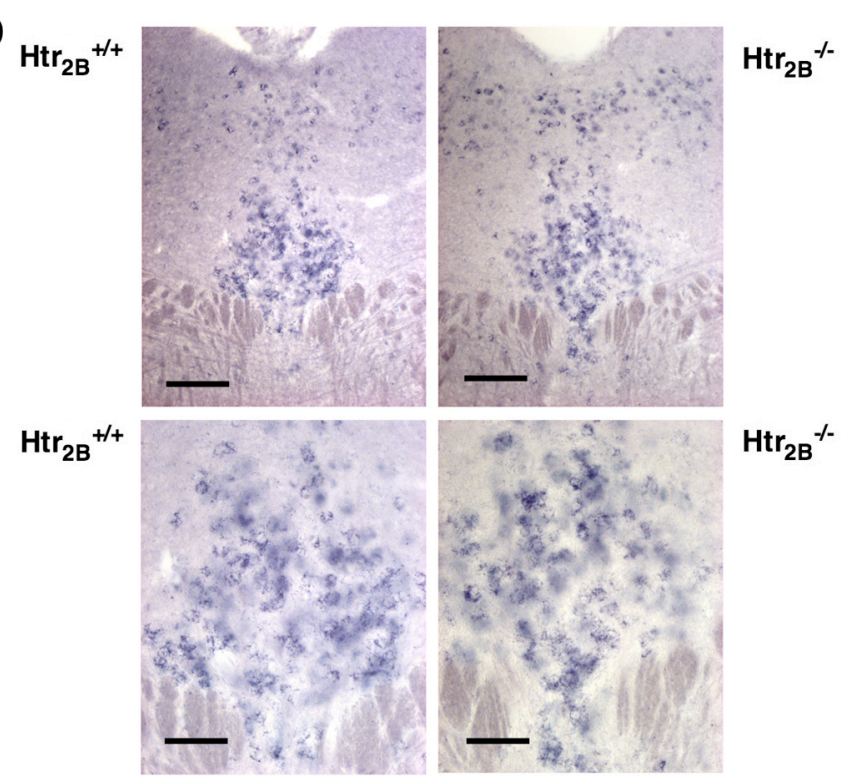

d

E

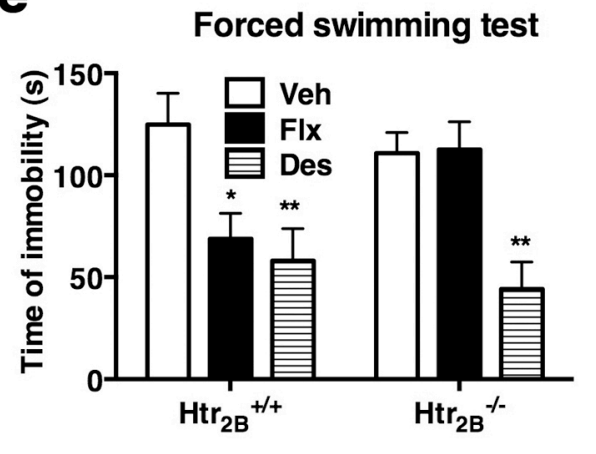

Figure 4. Reversal of behavioral parameters affected by chronic social isolation following antidepressant treatment. (a) Experimental design to evaluate behavioral and histological parameters after social chronic isolation in $\mathrm{Htr}_{2 B}{ }^{+/+}$and $\mathrm{Htr}_{2 B}{ }^{-/-}$mice. (b) Sert mRNA levels in the dorsal raphe determined by in situ hybridization was evaluated in $\mathrm{Htr}_{2 B}{ }^{-/}$mice compared to $\mathrm{Htr}_{2 B}{ }^{+/+}$mice. Representative Sert mRNA labeling in the dorsal raphe of $\mathrm{Htr}_{2 B}{ }^{+/+}$and $\mathrm{Htr}_{2 B}{ }^{-1-}$ mice sowed no expression difference (scale bar, top $25 \mu \mathrm{m}$, bottom $50 \mu \mathrm{m}$ ). Binding assay was performed with the NET radioligand Nisoxetine with various concentrations of imipramine on membranes prepared from the locus coeruleus (c) or VTA (d) showed no differences between genotypes. (e) The time of immobility in the forced swimming test measured following 4 weeks of chronic isolation was decreased by Flx $3 \mathrm{mg} / \mathrm{kg}$ and Des $5 \mathrm{mg} / \mathrm{kg}$ treatments in $\mathrm{Htr}_{2 B}{ }^{+/+}$but only by Des in $\mathrm{Htr}_{2 B}{ }^{-/ /}$mice. Data are expressed as mean \pm SEM ( $\mathrm{n}=5-6$ mice for each group) and was analyzed by Two-way ANOVA followed by Bonferroni post-hoc test; ** $\mathrm{p}<0.01$ compared to Veh groups. 


\section{Figure 5}
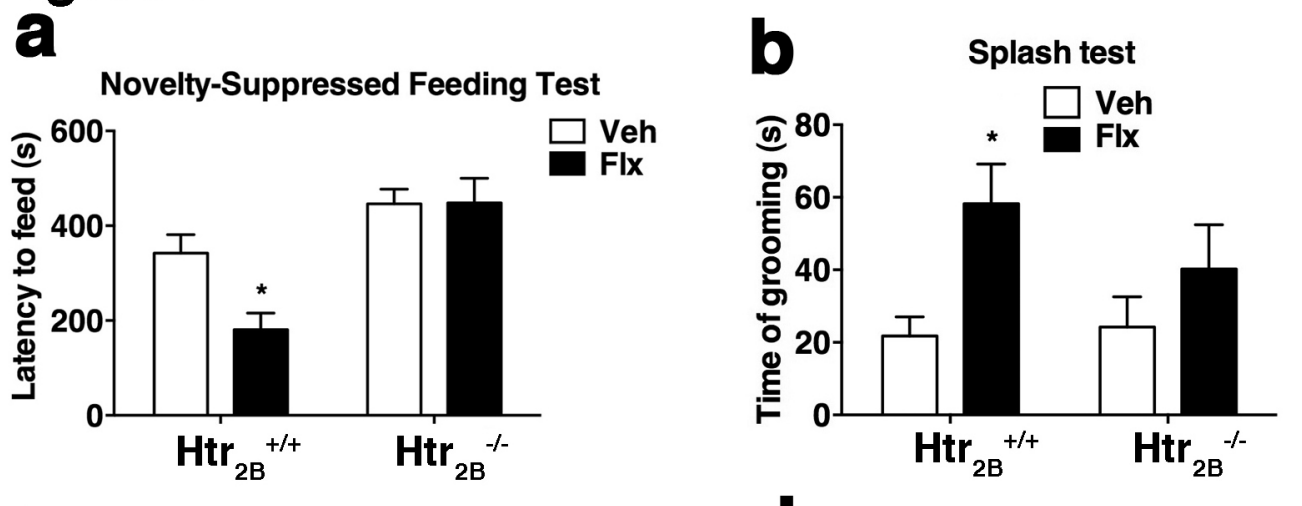

C Cell proliferation in the dorsal DG

d
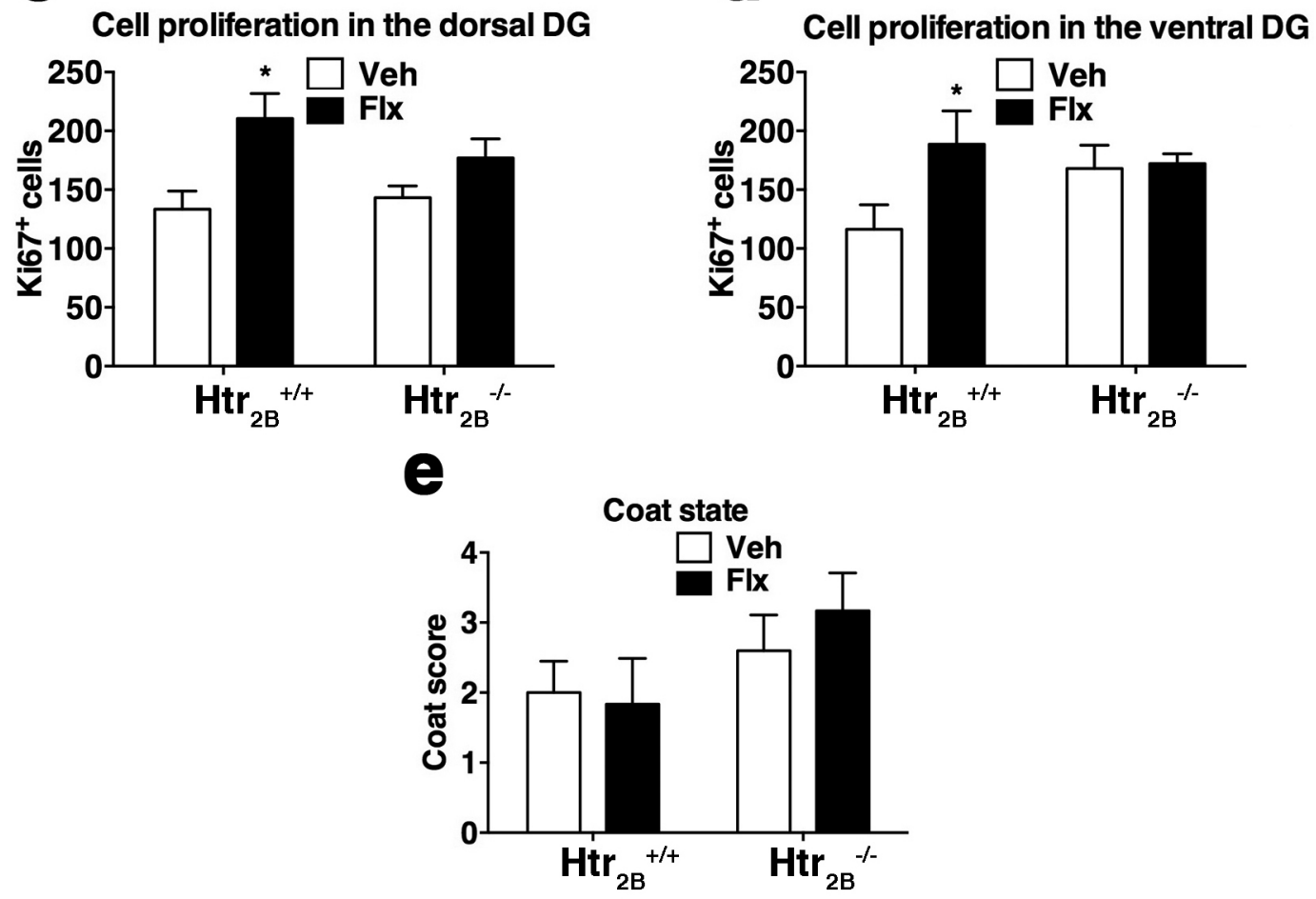

Figure 5. Reversal of behavioral and neurogenic parameters after chronic social isolation and chronic fluoxetine treatment. NSF test, Splash test, and Coat state were evaluated at the end of the 8 weeks of chronic isolation, plus concomitant Flx $(3 \mathrm{mg} / \mathrm{kg})$ or Veh treatment, during the last 4 weeks. Brains were collected at the end of the experimental protocol to perform the cell proliferation assay. (a) The latency to feed in the NSF (b) the time spent doing grooming in the Splash test, and the cell proliferation in the dorsal (c) and ventral (d) DG were improved by Flx in $\mathrm{Htr}_{2 B}{ }^{+/+}$but not $\mathrm{Htr}_{2 B}{ }^{-/-}$mice, while (e) the state of the coat was not modified by Flx treatment in either genotype. Data are expressed as mean \pm SEM ( $n=5-6$ mice for each group) and was analyzed by Two-way ANOVA followed by Bonferroni post-hoc test; $* \mathrm{p}<0.05$ compared to Veh groups. 
Table 1

Summary of statistical analysis

\begin{tabular}{|c|c|c|c|c|c|c|c|}
\hline Paradigm or assay & Parameter & Statistical test & Comparison & Statistics & Deg.freedom & $\mathrm{p}$ & Fig. \\
\hline NSF Test & Latency to feed & Unpaired $t$ test & $\operatorname{Htr}_{2 \mathrm{~B}}{ }^{+/+}$vs. $\mathrm{Htr}_{2 \mathrm{~B}}{ }^{-/-}$ & $\mathrm{t}=2.550$ & & 0.0435 & 1.a \\
\hline Home cage feed & Food cons. & Unpaired t test & $\mathrm{Htr}_{2 \mathrm{~B}}{ }^{+/+}$vs. $\mathrm{Htr}_{2 \mathrm{~B}}{ }^{-/-}$ & $\mathrm{t}=0.1203$ & & ns & $1 . \mathrm{b}$ \\
\hline \multirow{5}{*}{ Sucrose consumption } & \multirow{5}{*}{$\begin{array}{l}\% \text { Sucrose } \\
\text { preference }\end{array}$} & \multirow{3}{*}{$\begin{array}{l}\text { Two-way } \\
\text { ANOVA }\end{array}$} & Interaction & $\mathrm{F}=1.43$ & 1,39 & ns & \multirow{5}{*}{ 1.c } \\
\hline & & & Factor Genotype & $\mathrm{F}=5.89$ & 1,39 & 0.0199 & \\
\hline & & & Factor $\%$ sucrose & $\mathrm{F}=23.31$ & 1,39 & $<0.0001$ & \\
\hline & & \multirow{2}{*}{$\begin{array}{c}\text { Bonferroni } \\
\text { post-test }\end{array}$} & $\begin{array}{c}\operatorname{Htr}_{2 \mathrm{~B}}{ }^{+/+} \text {vs. } \mathrm{Htr}_{2 \mathrm{~B}}{ }^{-/-} \text {in } \\
\text { sucr. } 2 \%\end{array}$ & & & $<0.05$ & \\
\hline & & & $\begin{array}{c}\mathrm{Htr}_{2 \mathrm{~B}}^{+/+} \text {vs. } \mathrm{Htr}_{2 \mathrm{~B}}{ }^{-/-} \text {in } \\
\text { sucr. } 8 \%\end{array}$ & & & ns & \\
\hline ISH & $\mathrm{BDNF}^{+}$cells & Unpaired $t$ test & $\mathrm{Htr}_{2 \mathrm{~B}}^{+/+}$vs. $\mathrm{Htr}_{2 \mathrm{~B}}{ }^{-/-}$ & $\mathrm{t}=6.018$ & & $<0.0001$ & $1 . \mathrm{d}$ \\
\hline IF & $\mathrm{BDNF}^{+}$signal & Unpaired t test & $\mathrm{Htr}_{2 \mathrm{~B}}{ }^{+/+}$vs. $\mathrm{Htr}_{2 \mathrm{~B}}{ }^{-/-}$ & $\mathrm{t}=2.725$ & & 0.0234 & 1.e \\
\hline Western blot & F. 1. TrkB levels & Unpaired $t$ test & $\mathrm{Htr}_{2 \mathrm{~B}}{ }^{+/+}$vs. $\mathrm{Htr}_{2 \mathrm{~B}}{ }^{-/-}$ & $\mathrm{t}=0.91$ & & ns & \\
\hline Western blot & $\begin{array}{c}\text { Trunc TrkB } \\
\text { levels }\end{array}$ & Unpaired t test & $\mathrm{Htr}_{2 \mathrm{~B}}^{+/+}$vs. $\mathrm{Htr}_{2 \mathrm{~B}}^{-/-}$ & $\mathrm{t}=0.02$ & & ns & $1 . f$ \\
\hline Western blot & p75 levels & Unpaired $t$ test & $\mathrm{Htr}_{2 \mathrm{~B}}{ }^{+/+}$vs. $\mathrm{Htr}_{2 \mathrm{~B}}{ }^{-/-}$ & $\mathrm{t}=1.58$ & & ns & $1 . g$ \\
\hline \multirow{5}{*}{ Locomotor activity } & \multirow{5}{*}{ Squares crossed } & \multirow{3}{*}{$\begin{array}{l}\text { Two-way } \\
\text { ANOVA }\end{array}$} & Interaction & $\mathrm{F}=4.753$ & 1,36 & 0,0359 & \multirow{5}{*}{ 2.a } \\
\hline & & & Factor Genotype & $\mathrm{F}=6,093$ & 1,36 & 0,0185 & \\
\hline & & & Factor Area & $\mathrm{F}=296,9$ & 1,36 & $<0.0001$ & \\
\hline & & \multirow{2}{*}{$\begin{array}{l}\text { Bonferroni } \\
\text { post-test }\end{array}$} & $\begin{array}{c}\operatorname{Htr}_{2 \mathrm{~B}}{ }^{+/+} \text {vs. } \mathrm{Htr}_{2 \mathrm{~B}}{ }^{-/-} \text {in } \\
\text { CA }\end{array}$ & & & ns & \\
\hline & & & $\begin{array}{c}\mathrm{Htr}_{2 \mathrm{~B}}{ }^{+/+} \text {vs. } \mathrm{Htr}_{2 \mathrm{~B}}{ }^{-/-} \text {in } \\
\text { PA }\end{array}$ & & & $<0.05$ & \\
\hline Elev. plus maze & $\begin{array}{l}\text { Time in close } \\
\text { arms }\end{array}$ & Unpaired $t$ test & $\operatorname{Htr}_{2 \mathrm{~B}}^{+/+}$vs. $\mathrm{Htr}_{2 \mathrm{~B}}{ }^{-/-}$ & $\mathrm{t}=0.2196$ & & ns & $2, \mathrm{~b}$ \\
\hline \multirow{5}{*}{ Coat state } & \multirow{5}{*}{ Coat score } & \multirow{3}{*}{$\begin{array}{l}\text { Two-way } \\
\text { ANOVA }\end{array}$} & Interaction & $\mathrm{F}=0.374$ & 1,54 & ns & \multirow{5}{*}{ 3.a } \\
\hline & & & Factor Genotype & $\mathrm{F}=0.987$ & 1,54 & ns & \\
\hline & & & Factor Treatment & $\mathrm{F}=22.45$ & 1,54 & $<0.0001$ & \\
\hline & & \multirow{2}{*}{$\begin{array}{l}\text { Bonferroni } \\
\text { post-test }\end{array}$} & $\begin{array}{c}\text { Basal vs. Chr. isol. in } \\
\operatorname{Htr}_{2 \mathrm{~B}}^{+/+}\end{array}$ & & & $<0.05$ & \\
\hline & & & $\begin{array}{l}\text { Basal vs. Chr. isol. in } \\
\operatorname{Htr}_{2 \mathrm{~B}}{ }^{-/-}\end{array}$ & & & $<0.01$ & \\
\hline \multirow{5}{*}{ Splash test } & \multirow{5}{*}{$\begin{array}{l}\text { Time of } \\
\text { grooming }\end{array}$} & \multirow{3}{*}{$\begin{array}{l}\text { Two-way } \\
\text { ANOVA }\end{array}$} & Interaction & $\mathrm{F}=0.372$ & 1,24 & ns & \multirow{5}{*}{$3 . b$} \\
\hline & & & Factor Genotype & $\mathrm{F}=0.2218$ & 1,24 & ns & \\
\hline & & & Factor Treatment & $\mathrm{F}=45.81$ & 1,24 & $<0.0001$ & \\
\hline & & \multirow{2}{*}{$\begin{array}{c}\text { Bonferroni } \\
\text { post-test }\end{array}$} & $\begin{array}{c}\text { Basal vs. Chr. isol. in } \\
\operatorname{Htr}_{2 \mathrm{~B}}^{+/+}\end{array}$ & & & $<0.001$ & \\
\hline & & & $\begin{array}{l}\text { Basal vs. Chr. isol. in } \\
\operatorname{Htr}_{2 \mathrm{~B}}{ }^{-/-}\end{array}$ & & & $<0.01$ & \\
\hline \multirow{5}{*}{ Cell Proliferation } & \multirow{5}{*}{$\begin{array}{l}\mathrm{N}^{\circ} \text { of cells } \\
\mathrm{Ki} 67^{+}\end{array}$} & \multirow{3}{*}{$\begin{array}{l}\text { Two-way } \\
\text { ANOVA }\end{array}$} & Interaction & $\mathrm{F}=1.131$ & 1,32 & $\mathrm{~ns}$ & \multirow{5}{*}{ 3.c } \\
\hline & & & Factor Genotype & $\mathrm{F}=0.0357$ & 1,32 & ns & \\
\hline & & & Factor Treatment & $\mathrm{F}=16.5$ & 1,32 & 0.0003 & \\
\hline & & \multirow{2}{*}{$\begin{array}{c}\text { Bonferroni } \\
\text { post-test }\end{array}$} & $\begin{array}{c}\text { Basal vs. Chr. isol. in } \\
\operatorname{Htr}_{2 \mathrm{~B}}^{+/+}\end{array}$ & & & $<0.01$ & \\
\hline & & & $\begin{array}{l}\text { Basal vs. Chr. isol. in } \\
\operatorname{Htr}_{2 \mathrm{~B}}{ }^{-/-}\end{array}$ & & & ns & \\
\hline & & & Interaction & $\mathrm{F}=2.930$ & 2,25 & 0.072 & \\
\hline & & $\begin{array}{l}\text { Two-way } \\
\text { ANova }\end{array}$ & Factor Treatment & $\mathrm{F}=12.57$ & 2,25 & 0.0002 & \\
\hline & & & Factor Genotype & $\mathrm{F}=0.2298$ & 1,25 & ns & \\
\hline Forced Swimming Test & Immobility time & & Veh. vs. Flx. in $\operatorname{Htr}_{2 B}{ }^{+/+}$ & & & $<0.05$ & 4.e \\
\hline & & Bonferroni & Veh. vs. Flx. in $\mathrm{Htr}_{2 \mathrm{~B}}{ }^{-/-}$ & & & ns & \\
\hline & & post-test & Veh. vs. Des. in $\operatorname{Htr}_{2 B}{ }^{+/+}$ & & & $<0.01$ & \\
\hline & & & Veh. vs. Des. in $\mathrm{Htr}_{2 \mathrm{~B}}{ }^{-/-}$ & & & $<0.01$ & \\
\hline
\end{tabular}




\begin{tabular}{|c|c|c|c|c|c|c|c|}
\hline \multirow{5}{*}{$\begin{array}{c}\text { Novelty Suppressed } \\
\text { Feeding Test }\end{array}$} & \multirow{5}{*}{ Latency to feed } & \multirow{3}{*}{$\begin{array}{l}\text { Two-way } \\
\text { ANOVA }\end{array}$} & Interaction & $\mathrm{F}=3.877$ & 1,18 & 0.064 & \multirow{5}{*}{$5 . \mathrm{a}$} \\
\hline & & & Factor Treatment & $\mathrm{F}=3.689$ & 1,18 & 0.070 & \\
\hline & & & Factor Genotype & $\mathrm{F}=20.04$ & 1,18 & 0.0003 & \\
\hline & & \multirow{2}{*}{$\begin{array}{l}\text { Bonferroni } \\
\text { post-test }\end{array}$} & Veh. vs. Flx. in $\operatorname{Htr}_{2 \mathrm{~B}}{ }^{+/+}$ & & & $<0.05$ & \\
\hline & & & Veh. vs. Flx. in $\mathrm{Htr}_{2 \mathrm{~B}}{ }^{-/-}$ & & & ns & \\
\hline \multirow{5}{*}{ Splash test } & \multirow{5}{*}{$\begin{array}{l}\text { Time of } \\
\text { grooming }\end{array}$} & \multirow{3}{*}{$\begin{array}{l}\text { Two-way } \\
\text { ANOVA }\end{array}$} & Interaction & $\mathrm{F}=1.130$ & 1,16 & $\mathrm{~ns}$ & \multirow{5}{*}{$5 . b$} \\
\hline & & & Factor Treatment & $\mathrm{F}=7.456$ & 1,16 & 0.0148 & \\
\hline & & & Factor Genotype & $\mathrm{F}=0.6608$ & 1,16 & ns & \\
\hline & & \multirow{2}{*}{$\begin{array}{c}\text { Bonferroni } \\
\text { post-test }\end{array}$} & Veh. vs. Flx. in $\operatorname{Htr}_{2 \mathrm{~B}}{ }^{+/+}$ & & & $<0.05$ & \\
\hline & & & Veh. vs. Flx. in $\mathrm{Htr}_{2 \mathrm{~B}}{ }^{-/-}$ & & & ns & \\
\hline \multirow{5}{*}{$\begin{array}{c}\text { Cell Proliferation in the } \\
\text { dorsal DG }\end{array}$} & \multirow{5}{*}{$\begin{array}{l}\mathrm{N}^{\circ} \text { of cells } \\
\mathrm{Ki}_{67} 7^{+}\end{array}$} & \multirow{3}{*}{$\begin{array}{l}\text { Two-way } \\
\text { ANOVA }\end{array}$} & Interaction & $\mathrm{F}=1.479$ & 1,16 & $\mathrm{~ns}$ & \multirow{5}{*}{ 5.c } \\
\hline & & & Factor Treatment & $\mathrm{F}=9.669$ & 1,16 & 0.0067 & \\
\hline & & & Factor Genotype & $\mathrm{F}=0.4476$ & 1,16 & ns & \\
\hline & & \multirow{2}{*}{$\begin{array}{l}\text { Bonferroni } \\
\text { post-test }\end{array}$} & Veh. vs. Flx. in $\operatorname{Htr}_{2 \mathrm{~B}}{ }^{+/+}$ & & & $<0.05$ & \\
\hline & & & Veh. vs. Flx. in $\mathrm{Htr}_{2 \mathrm{~B}}{ }^{-/-}$ & & & ns & \\
\hline \multirow{5}{*}{$\begin{array}{l}\text { Cell Proliferation in the } \\
\text { ventral DG }\end{array}$} & \multirow{5}{*}{$\begin{array}{l}\mathrm{N}^{\circ} \text { of cells } \\
\mathrm{Ki} 67^{+}\end{array}$} & \multirow{3}{*}{$\begin{array}{l}\text { Two-way } \\
\text { ANOVA }\end{array}$} & Interaction & $\mathrm{F}=2.728$ & 1,16 & ns & \multirow{5}{*}{ 5.d } \\
\hline & & & Factor Treatment & $\mathrm{F}=3.443$ & 1,16 & 0.082 & \\
\hline & & & Factor Genotype & $\mathrm{F}=0.7309$ & 1,16 & ns & \\
\hline & & \multirow{2}{*}{$\begin{array}{c}\text { Bonferroni } \\
\text { post-test }\end{array}$} & Veh. vs. Flx. in $\mathrm{Htr}_{2 \mathrm{~B}}{ }^{+/+}$ & & & $<0.05$ & \\
\hline & & & Veh. vs. Flx. in $\mathrm{Htr}_{2 \mathrm{~B}}{ }^{-/-}$ & & & ns & \\
\hline \multirow{5}{*}{ Coat state } & \multirow{5}{*}{ Coat score } & \multirow{3}{*}{$\begin{array}{l}\text { Two-way } \\
\text { ANOVA }\end{array}$} & Interaction & $\mathrm{F}=0.4276$ & 1,18 & ns & \multirow{5}{*}{ 5.e } \\
\hline & & & Factor Treatment & $\mathrm{F}=0.1272$ & 1,18 & ns & \\
\hline & & & Factor Genotype & $\mathrm{F}=2.972$ & 1,18 & ns & \\
\hline & & \multirow{2}{*}{$\begin{array}{l}\text { Bonferroni } \\
\text { post-test }\end{array}$} & Veh. vs. Flx. in $\operatorname{Htr}_{2 \mathrm{~B}}{ }^{+/+}$ & & & ns & \\
\hline & & & Veh. vs. Flx. in $\mathrm{Htr}_{2 \mathrm{~B}}{ }^{-/-}$ & & & ns & \\
\hline
\end{tabular}

